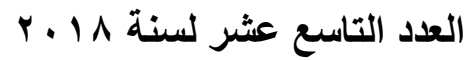

فاعلية برنامج قائم على نموذج وينينج لمستويات الاستقصاء فى اكتساب المفاهيم العلمية والقدرة على حل المشكلات والاتجاه نحو مادة العلوم لاى تلاميذ المرحلة الإعدادية

$$
\begin{aligned}
& \text { للبـاحثة } \\
& \text { بدر عبدالعزيز بريك } \\
& \text { (مدرسة علوم بمدرسة سب بوليو الإعدادية ) لورئ ) } \\
& \text { للحصول على درجة دكتور اه الفلسفة فى التربية } \\
& \text { مناهج وطرق تدريس (طرق تدريس العلوم) }
\end{aligned}
$$

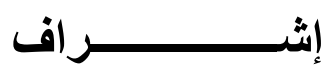

أ.د// نــــوال عبـد الـنتـاح فهمى خليل أستاذ المناهج وطرق تدريس العلوم

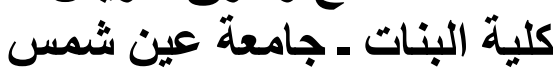

أ. د/ منى عبد الصبورمحمد شـهاب إبـاب أستاذ المناهج وطرق تدريس العلوم كلية البنات ـ جامعة عين شمس 


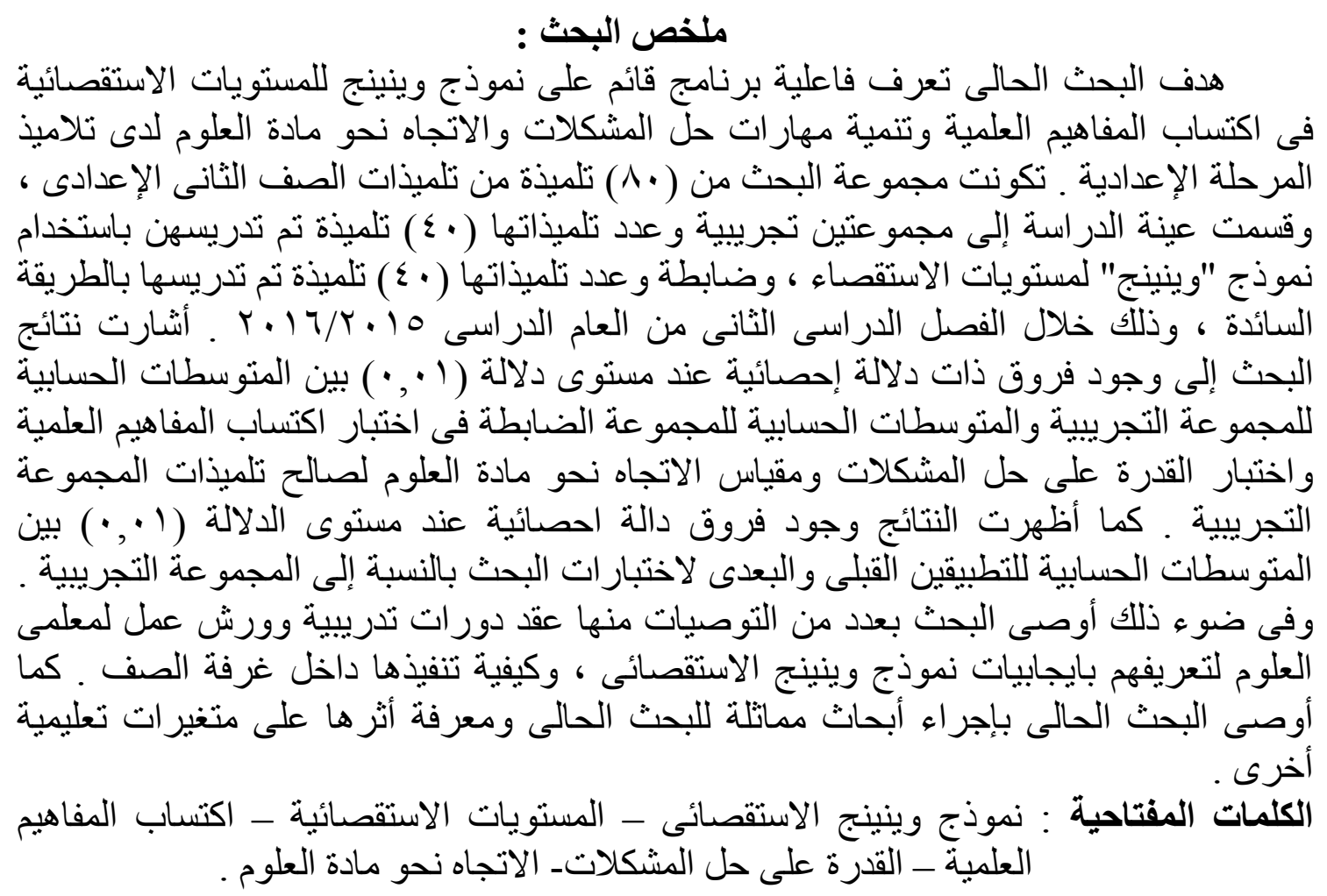

Abstract :

The aim of this study was to investigate the effect of program based on the levels of inquiry model on acquiring concepts, problem solving ability and attitudes toward science for $8^{\text {th }}$ grade students. The sample consisted of (80) students, whose divided into two groups, an experimental group ( $\mathrm{n}=$ 40 students) taught the science content using Wenning inquiry model and a control group ( $n=40$ students) taught the science content using the traditional method of teaching. The study lasted in the second semester of the 2015/ 2016 academic year. The results of the study revealed that there were significant statistical differences in acquiring concepts, problem solving ability and attitudes toward science in favour of the experimental group. Furthermore, the results showed that there were significant statistical differences between the pre- and post- test of the acquiring concepts test, problem solving ability test and attitudes toward science test for the experimental group, but only in the test as a whole for the control group. In the light of the above results, the study proposed several recommendations such as conducting training workshops for in- service science teachers on how to use Wenning inquiry model in science classes. Finally, the study recommends that further research in using levels of inquiry model in teaching science be conducted and relate this to some educational variables. 
Keywords: Wenning inquiry model - levels of inquiry - acquiring concepts - problem solving ability - attitudes toward science

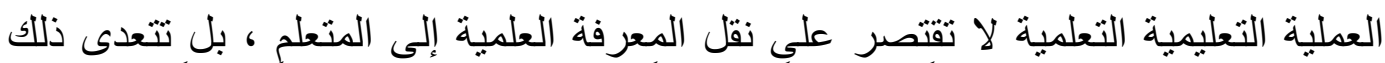

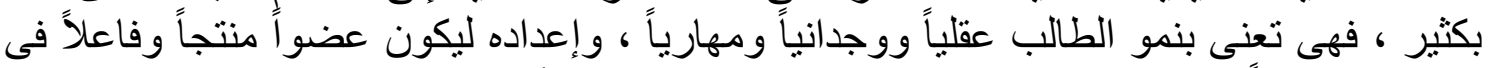

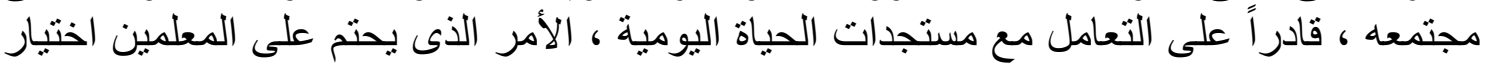

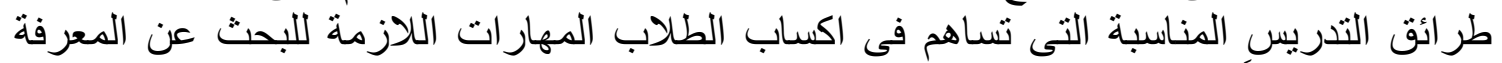
ومن الاستراتيجيات التدريسية التى تجعل المتعلم نشطاً وباحثاً ومفسراً ومكتشفاً للمعرفة التهاء

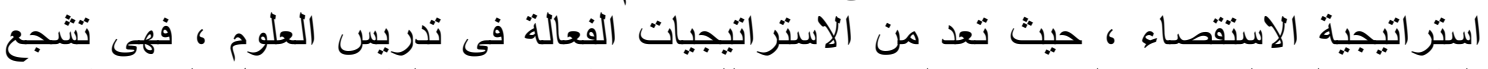

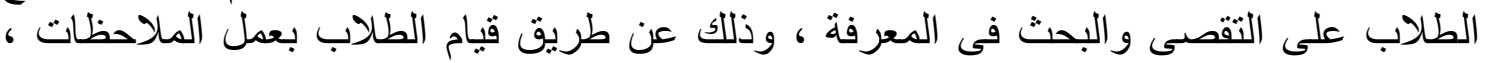

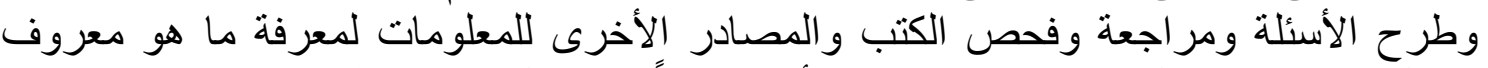

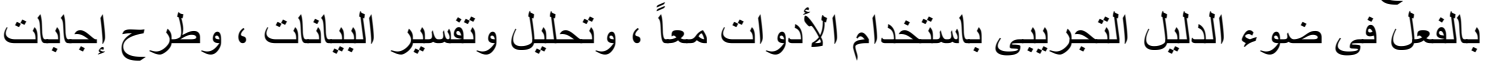

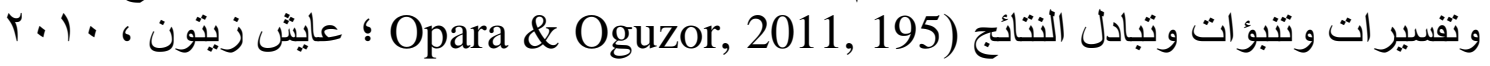

فالاستقصاء العلمى يستتد إلى فلسفة تعليمية حيث أن تعلم الطالب للمعرفة يكون ذا معنى إذا

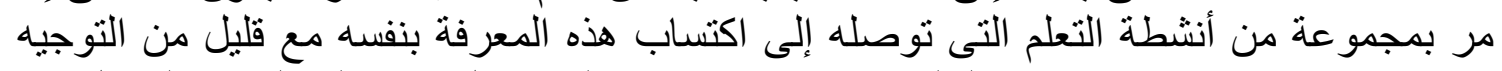
(Dunkhase, 2003, 10)

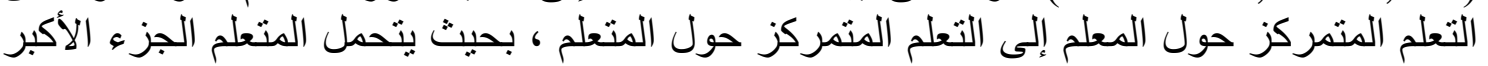

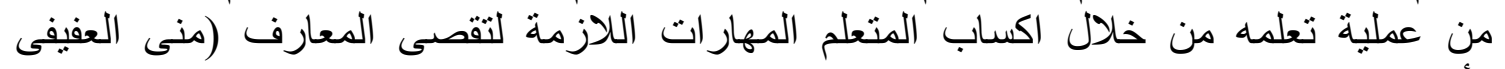

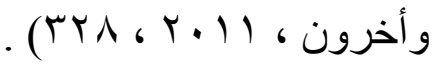
ولقد ظهرت عدة نماذج للتعلم القائم على الاستقصاء تركز على إيجابية المتعلم ونشاطه أثناء

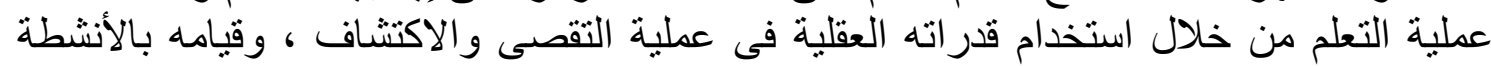

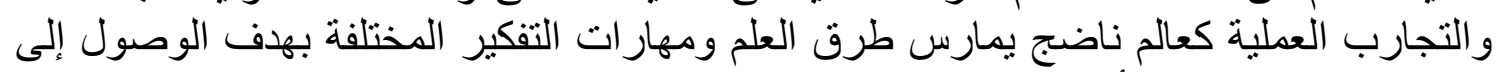

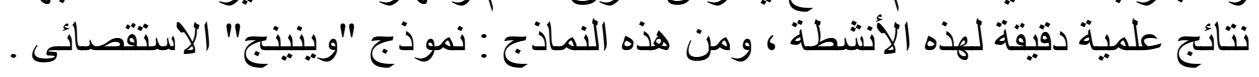
ويعد نموذج مستويات الاستقصاء (نموذج وينينج) من الأساليب الحديثة في التدريس القائم

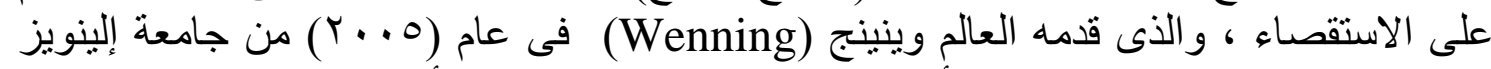
فى الولايات المتحدة الأمريكية ، وهو نموذج (Illinois)

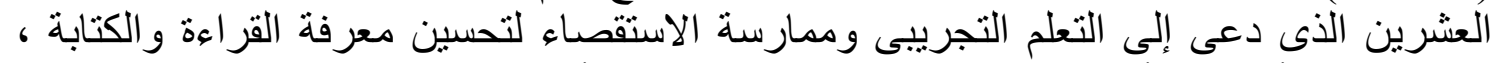

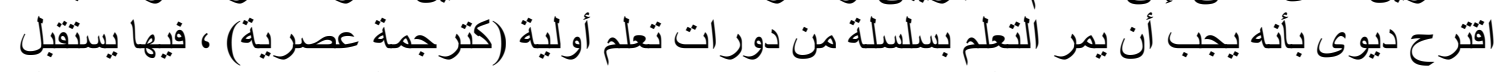

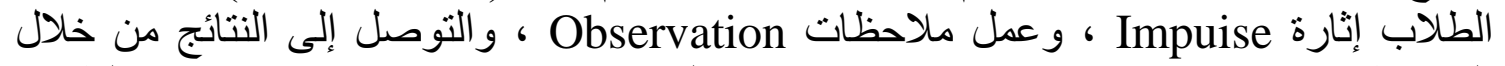

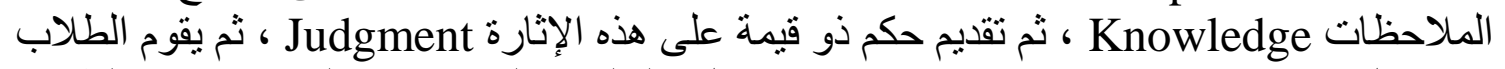

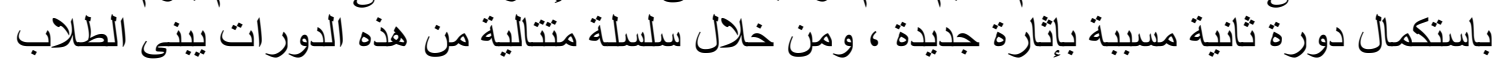

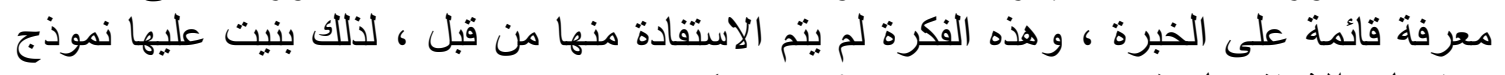

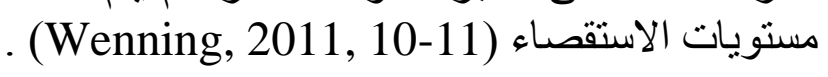

ويتضمن نموذج وينينج (Wenning) الاستقصائى على المستويات الاستقصائية الآتية :

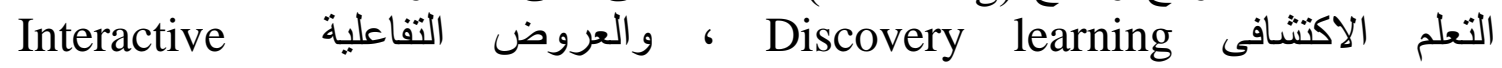

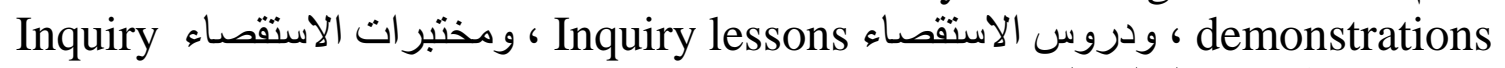
labs ، تطبيقات العالم الحقيقى Real-World Application ، والاستقصاء الافتراضى الاء 
كالقئ مypothetical inquiry كالتالى (Wenning, 2011, 12-13; Wenning, 2005, 4-10 )

ا - المستوى الأول : التعلم الاكتثافى : Discovery Learning

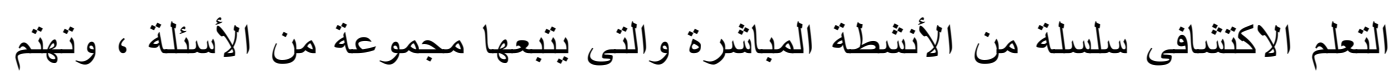

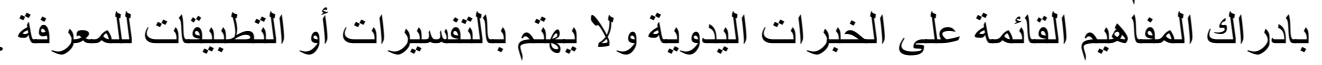

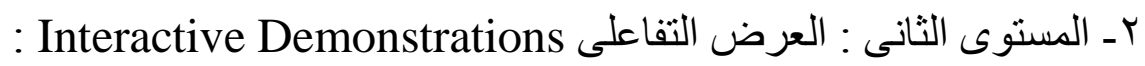
المعلم هو المسئول عن إجراء العرض الذئى ينسم بالتناقض المعرفى لتحدى الدفاهيم البديلة

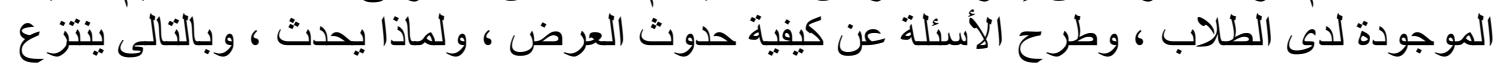

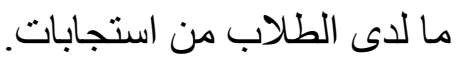

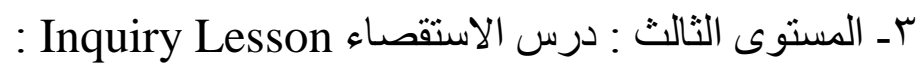

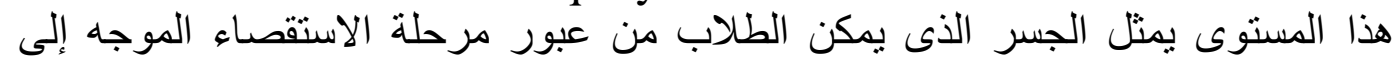

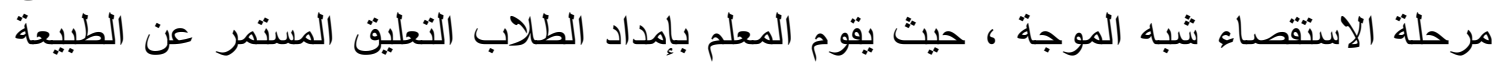

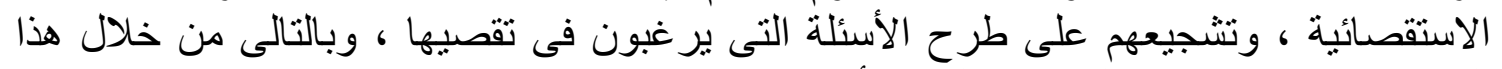

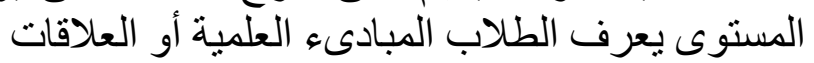

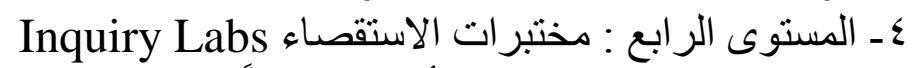

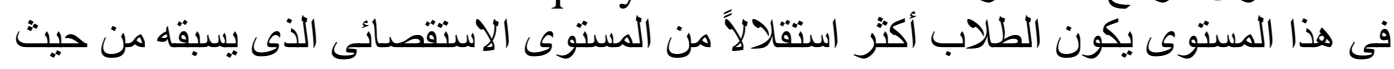

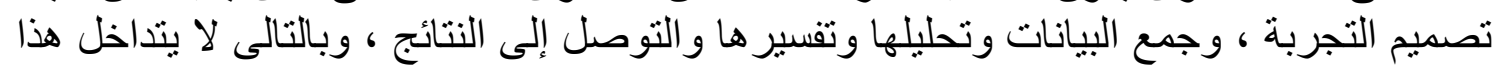

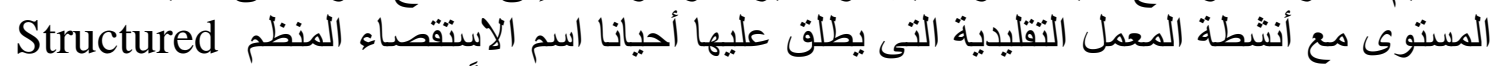

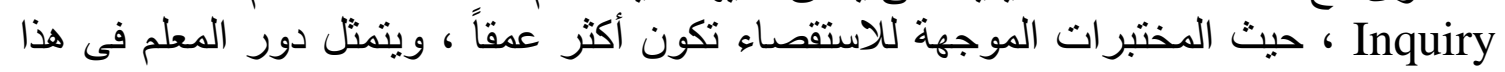

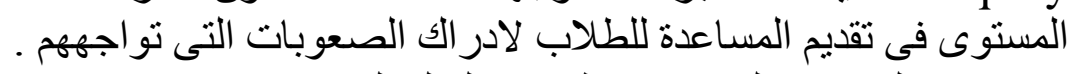

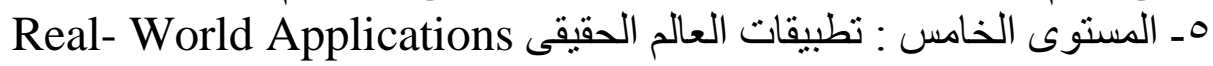

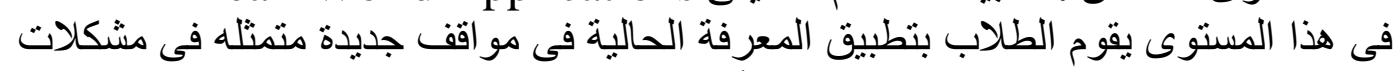

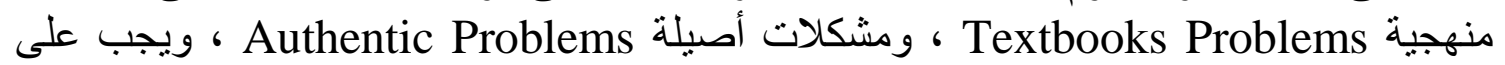

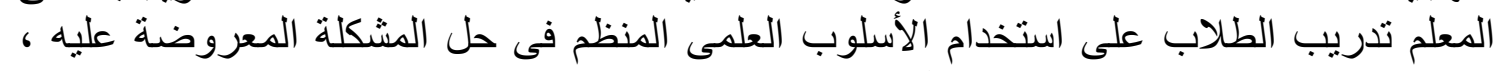
وبالنالى ينمى لدى الطلاب مهار ات حل المشكلات .

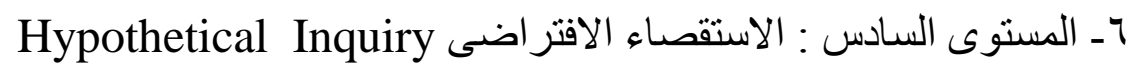

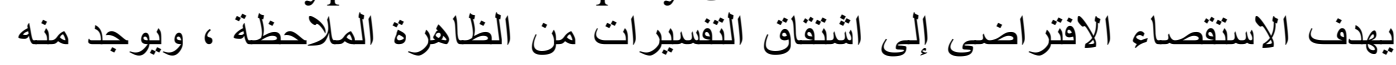

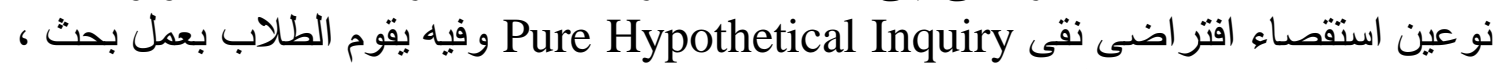

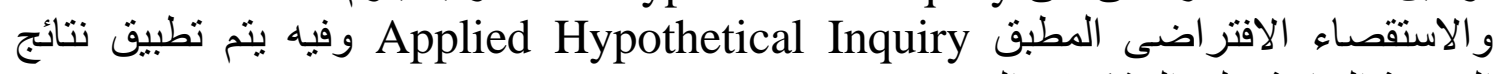

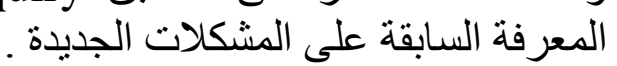

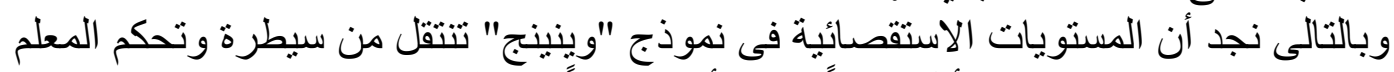

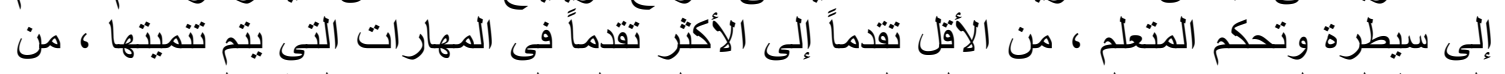

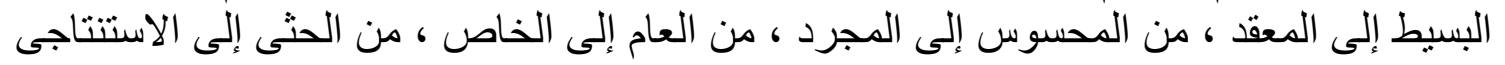

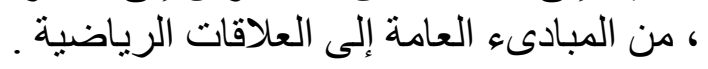

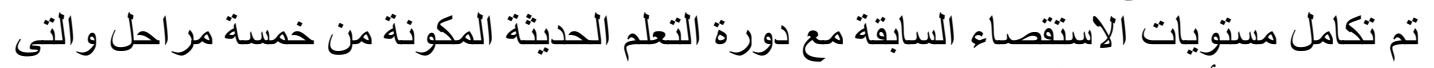
، تعتبر التركيب الأساسى لكل مستوى من مستويات الاستقصاء (Wenning, 2011, 11)

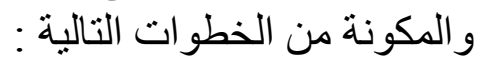




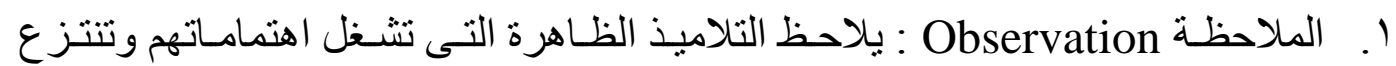

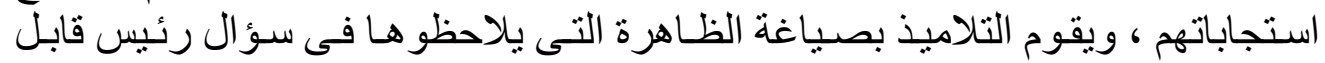
للبحثث و التقصى . ץ. المعالجة Manipulation : يقترح التلاميذ الأفكار التى يتم مناقثتها ، وتتميـة المداخل

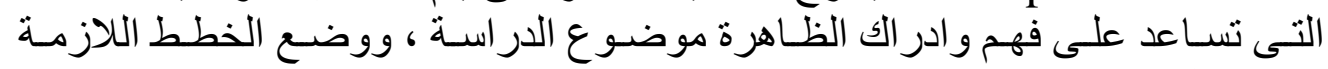
لتجميع البيانات الكمية والنئ فئ والنية

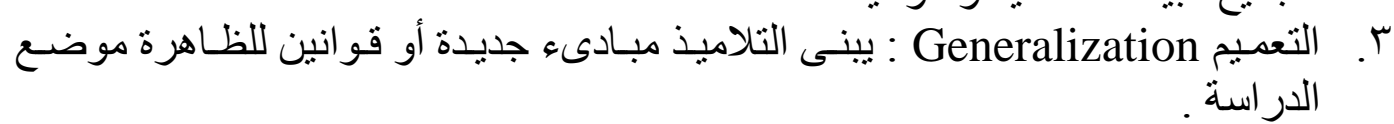
ع. التحقق Verification : يقوم التلاميذ بعمل تنبؤات وبناء اختبار باستخدام القانون العام المستتتج من الخطوة السابقة . لإنوم ๑. التطبيق Application : يصيغ التلاميذ الاستنتاجات التى تم الاتفاق عليها والتى تم

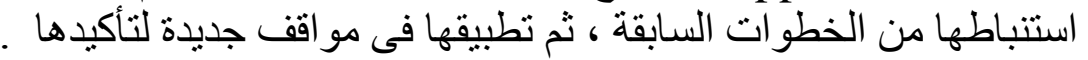

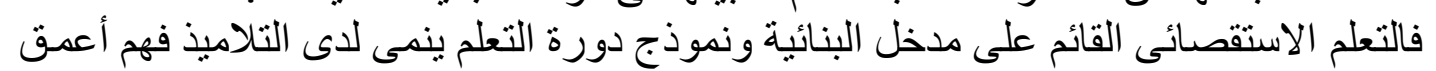

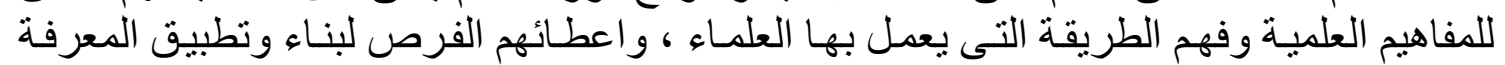

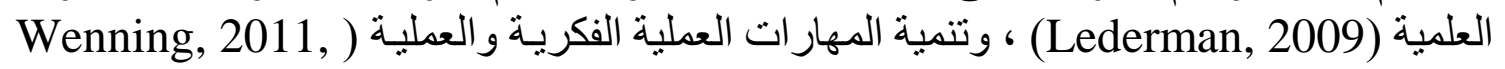

ومن الدراسات التى بحثت أثر نموذج وينينج لمستويات الاستقصاء فى تدريس العلوم ، دراسة كل من (Achmad \& Suhandi, 2017) التى هدفت إلى استقصاء أثر نموذج مستويات Scientific Literacy domain الاستقصاء فى تنمية المعرفة العلمية مجال الاتجاهات ، Interactive Lecture Demonstration ومقارنته بطريقة العرض التفاعلى attitudes

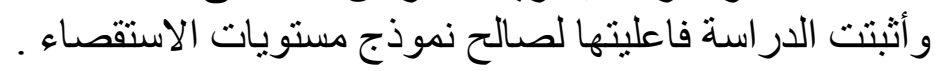

و هدفت دراسة (Hardianti \& Kuswanto, 2017) إلى اكتشاف الاختلاف فى الفاعلية

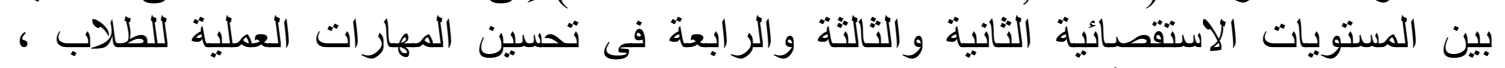

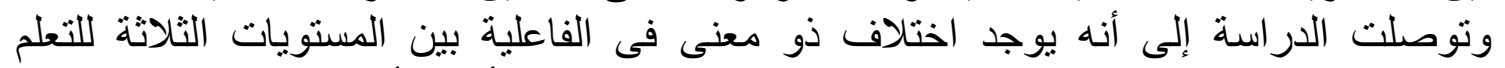

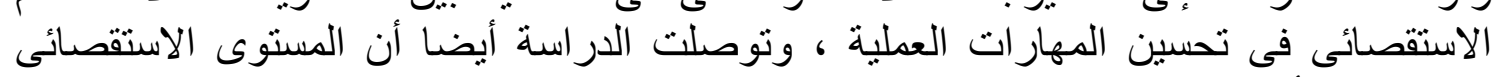

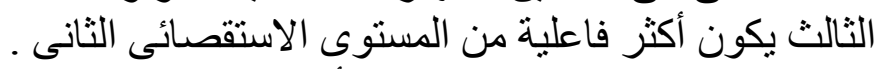

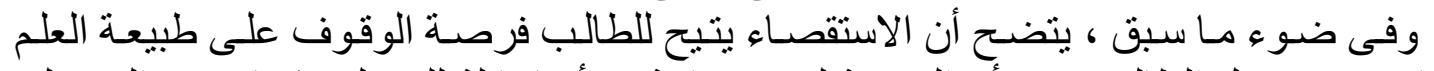

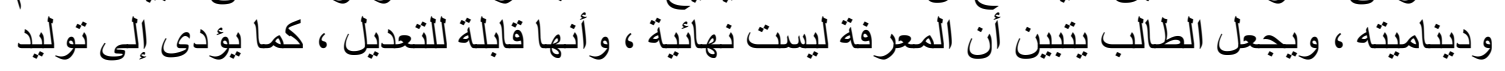

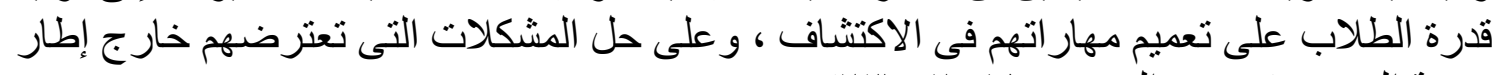

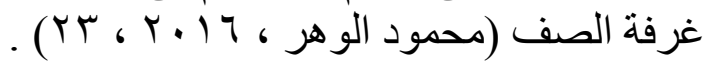

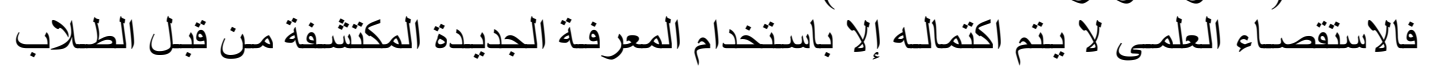

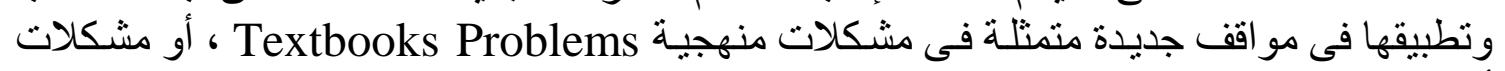

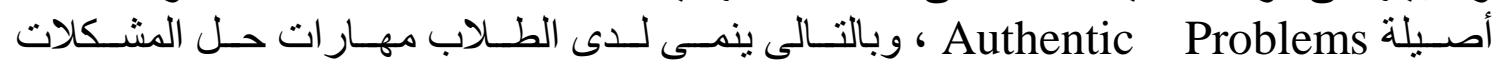
(Wenning, 2011, 18)

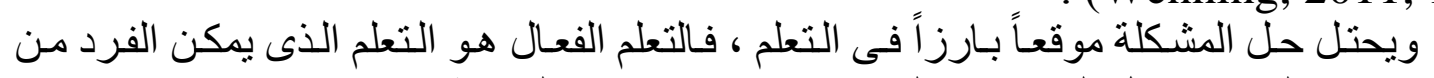

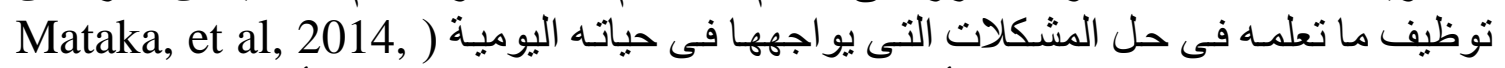

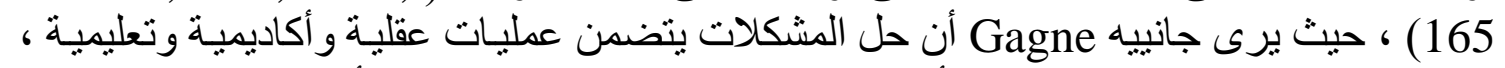

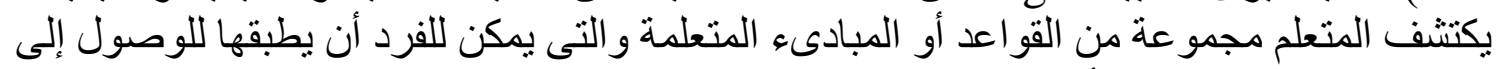

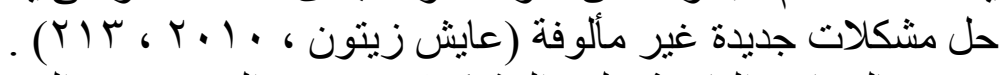

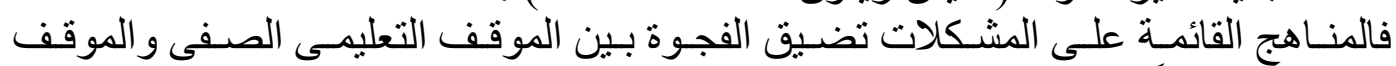

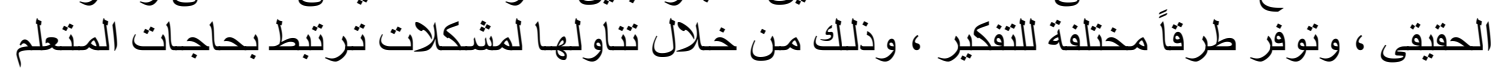


و اهتماماته من جهة ، و تتفق مع مو اقف البحث و التقصى من جهة أخرى (فتحى سبيتان ، . ب ، ،

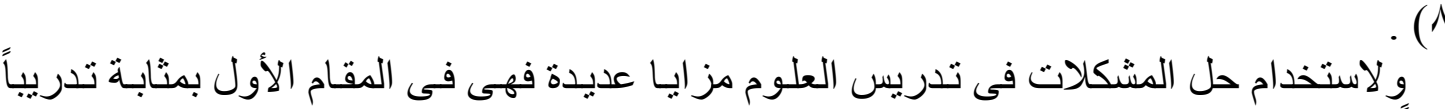

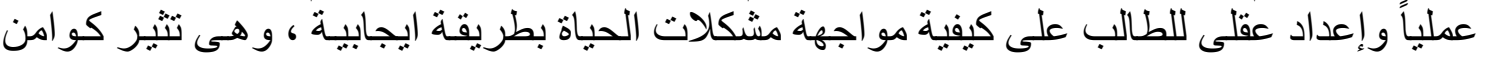

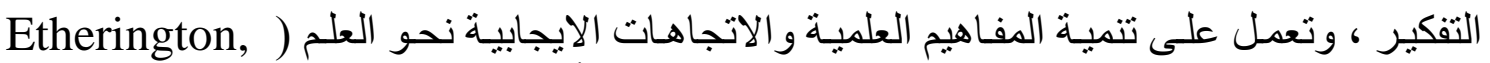

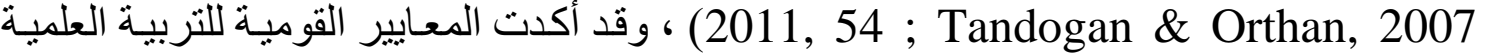

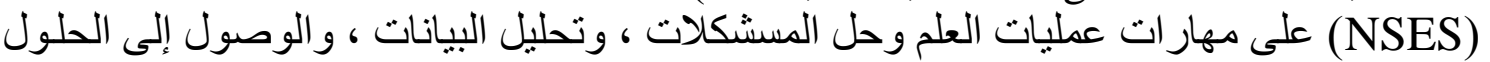

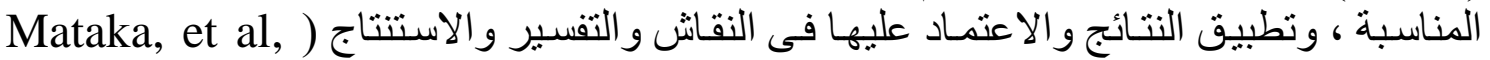
. (2014, 164-165 ; Fatoke \& Olaoluwa, 2014, 50

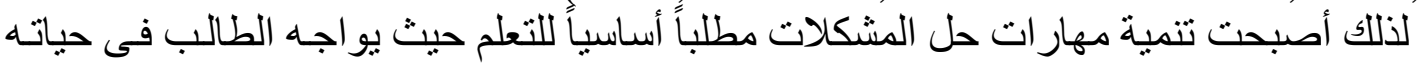

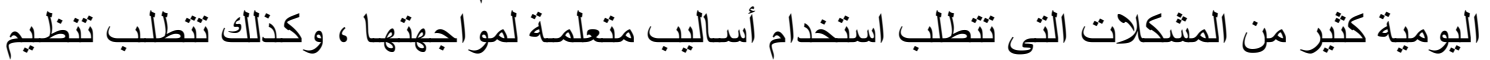

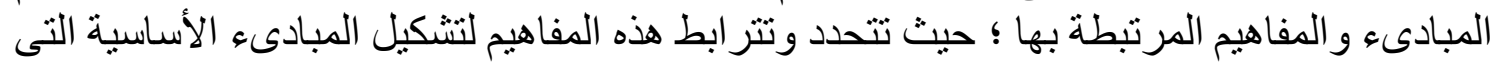
بدور ها تستخدم فى حل المن المنكلة

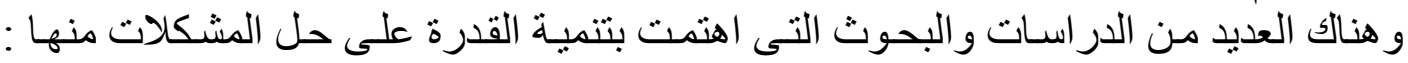

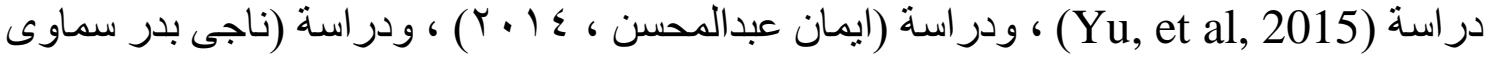

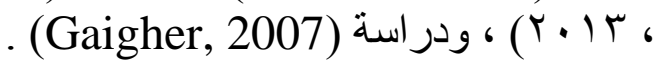

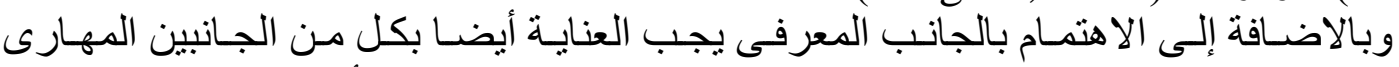

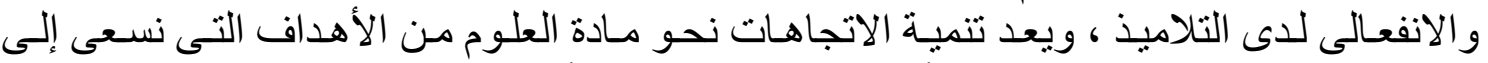

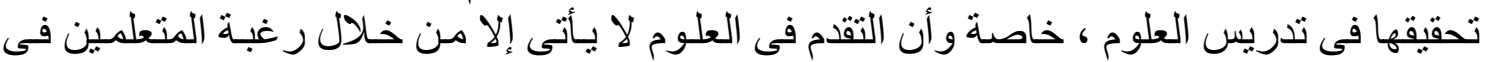

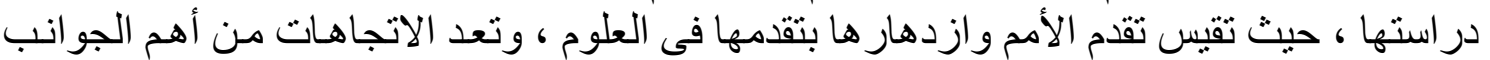

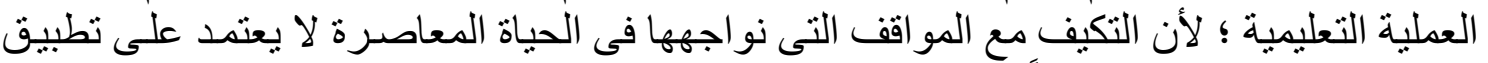

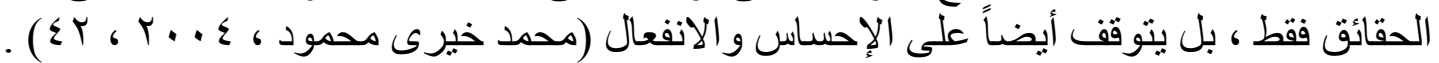

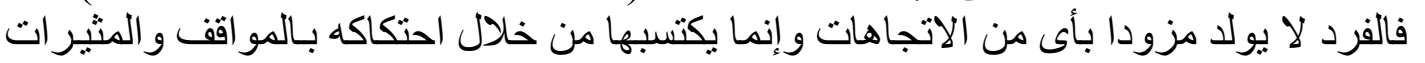

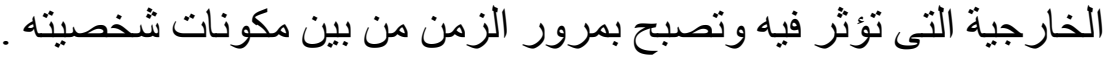

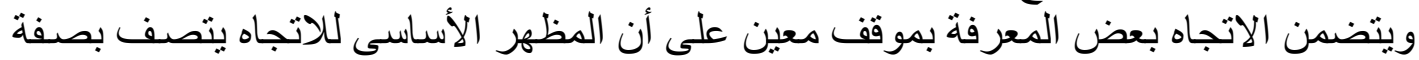

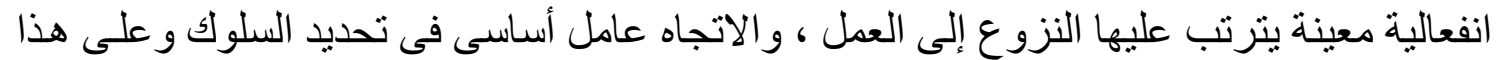

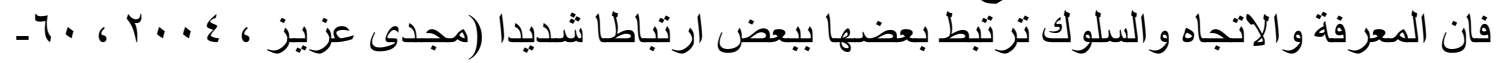

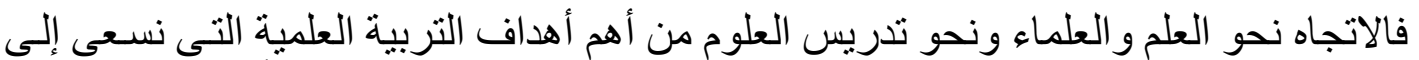
( 79

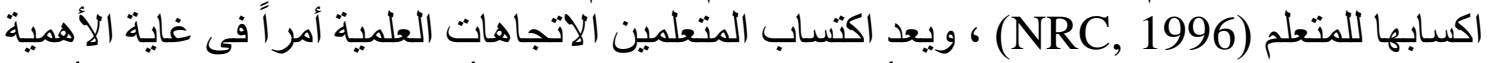

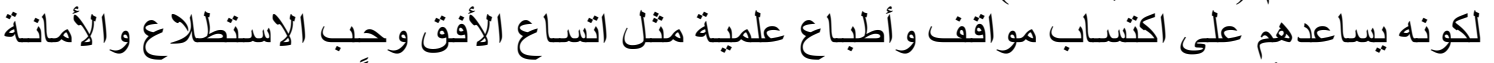

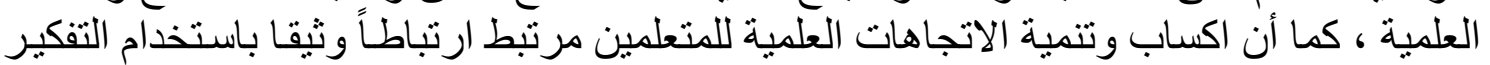

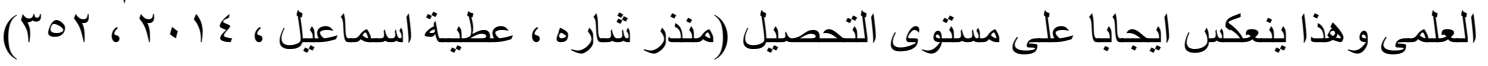

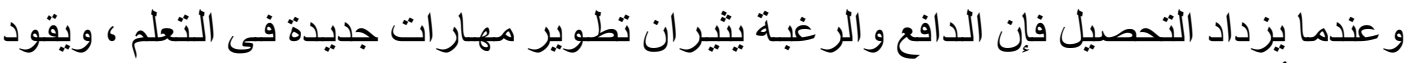

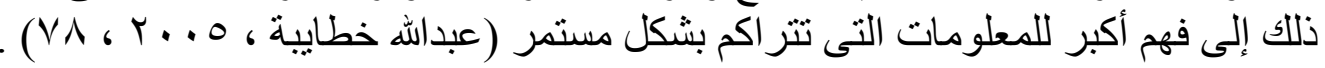

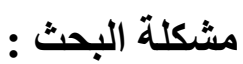

نظر اً لاهتمام مناهج العلوم بالمفاهيم المجردة و الظو اهر و الأحداث الطبيعية المحيطة بـالمتعلم

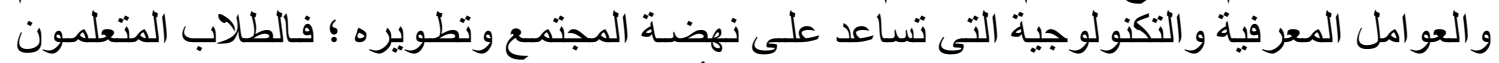

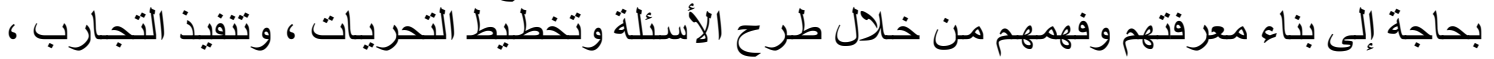

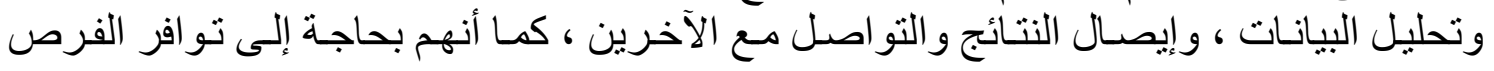


الكافية للتقدم من المحسوس إلى تجريد أفكار هم و إعادة التفكير فى فرضياتهم ، و وإعادة التجارب ،

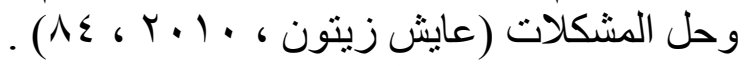

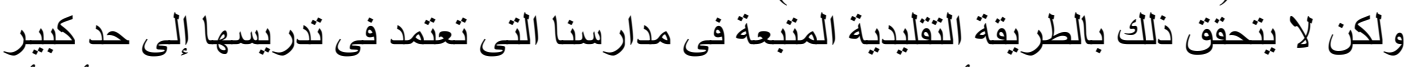

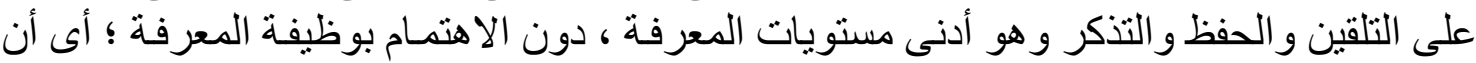

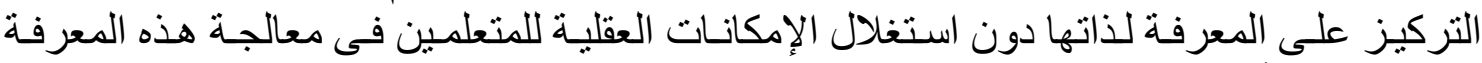

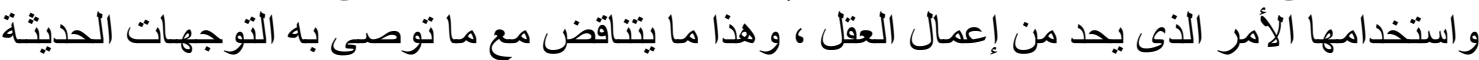

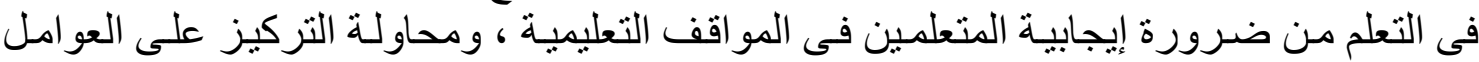

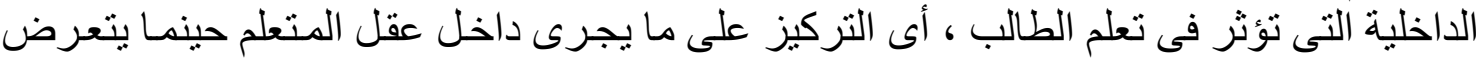

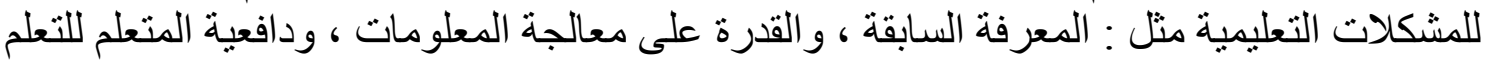

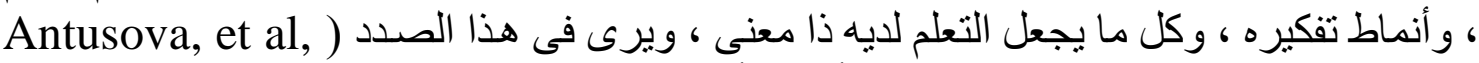
(2014, 2 ; Ali Khan, 2009, 43

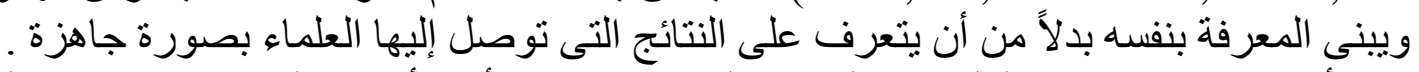

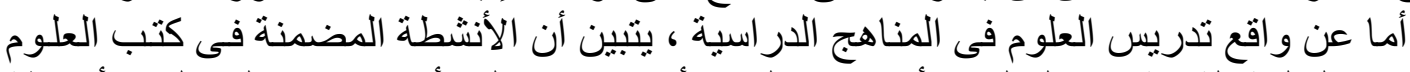

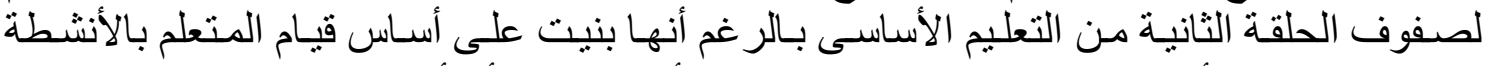

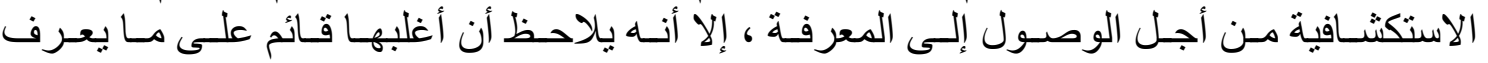

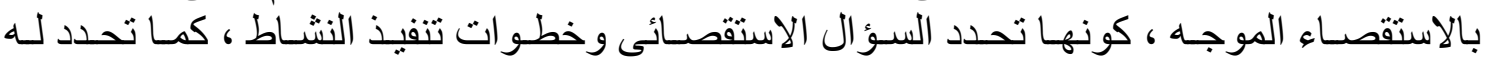

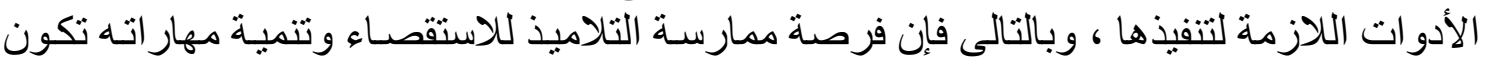

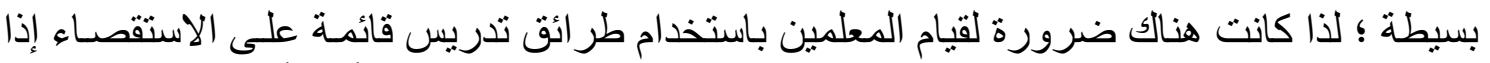

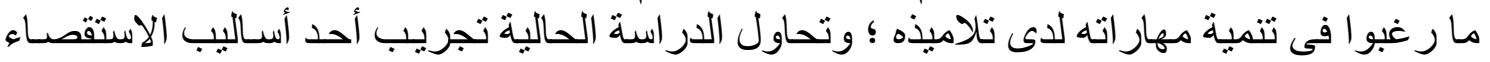

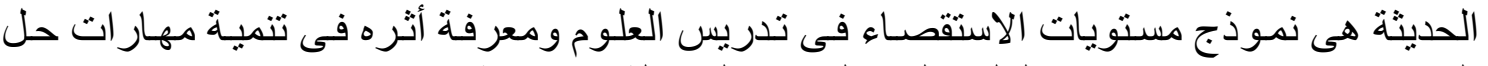

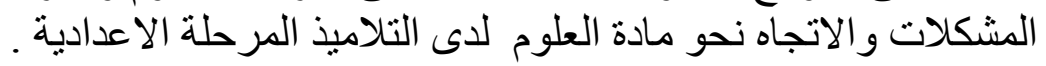
تحديد المشكلة :

مما سبق ينبين ضعف في استخدام الأنشطة الاستقصائية و انخفاض مستوى تحصيل الدفاهيم

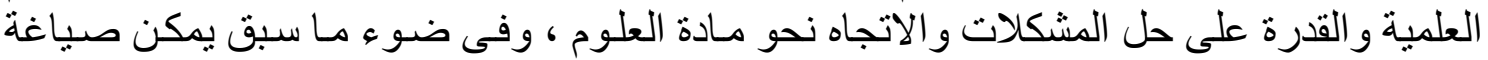

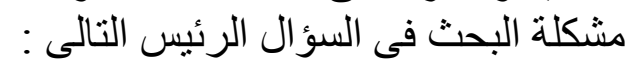

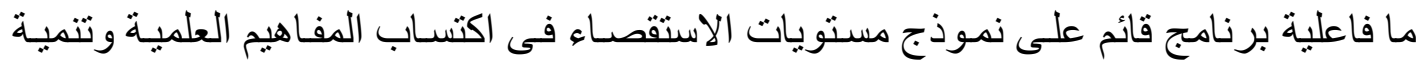
مهار ات حل المشكلات و الاتجاه نحو مادة العاد العلوم لدى تلاميذ المرحلة الإعدادية ؟

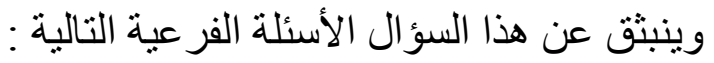

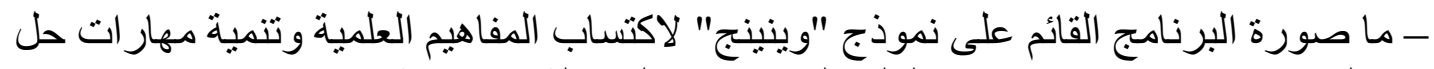

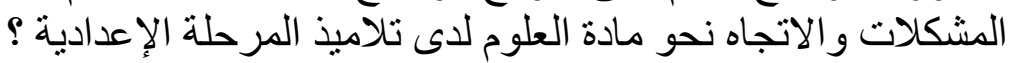

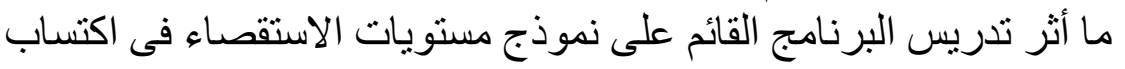

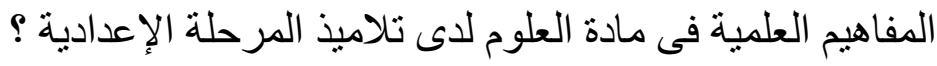

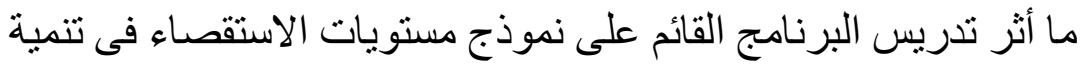

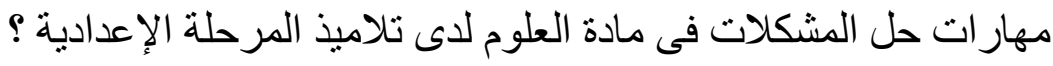

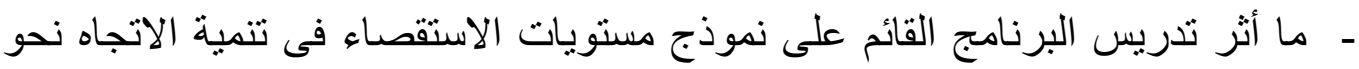
مادة العلوم لدى تلاميذ المرحلة الإعدادى ؟ برج فروض البحث : ان إمام البحث الحالى على الفروض التالية :

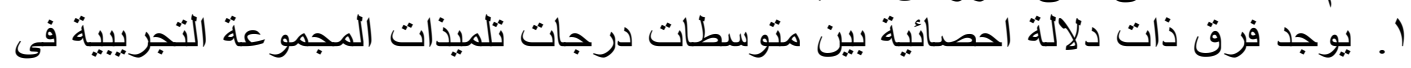
التطبيقين القبلى والبعدى لاختبار اكتساب المفاهيم العلمية ، لصالح التطبيق البعدى . 
Y. يوجد فرق ذات دلالة إحصائية بين متوسطات درجات تلميذات المجموعتين التجريبية

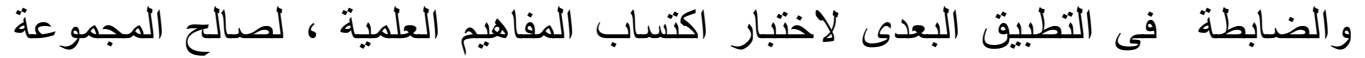
التجريبية .

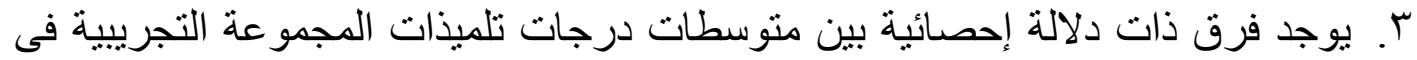

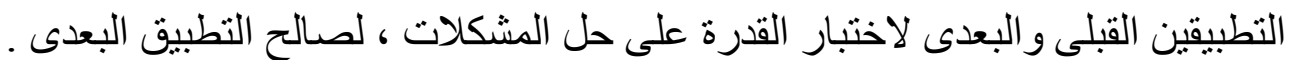

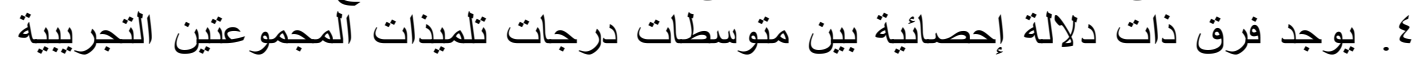

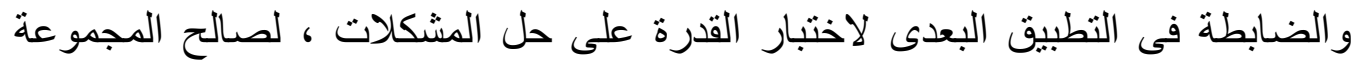
التجريبية.

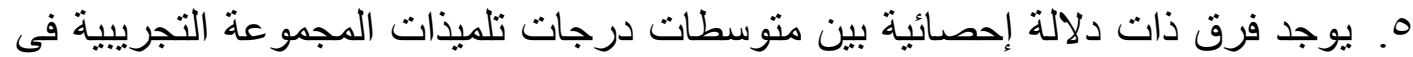

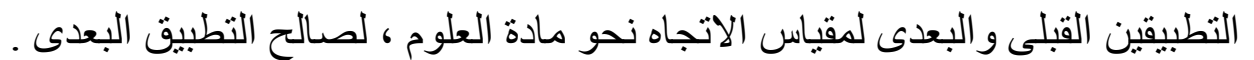

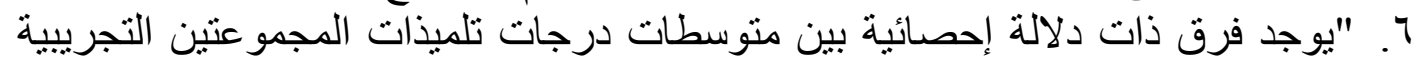

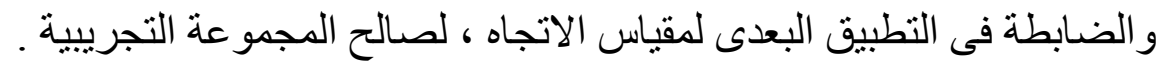

$$
\text { أهداف البحث : البحث الحالى تعرف : }
$$

ا. اكتساب المفاهيم فى مادة العلوم لاى تلاميذ المرحلة الإعدادية باستخدام برنامج مقترح قائم r. تنمية مهار على حل المشكلات فى مادة العلوم لاى تلاميذ المرحلة الإعدادية باستخدام

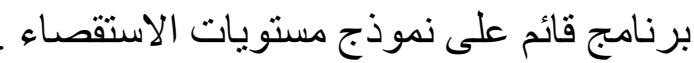

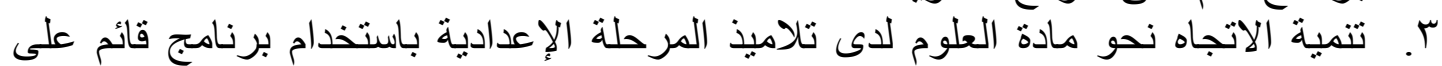

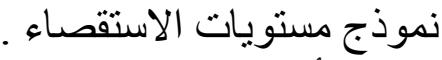
ء. تعرف أثر البرنامج القائم على نموذج "وينينج" فئى اكتساب المفاهيم العلمية وتنمية مهار ات حل المشكلات و الاتجاه نحو مادة العلوم لدى تلاميذ المرحلة الإعدادية .

$$
\text { أهمية البحث : أهمية هذا البحث فى أنه : }
$$

ا. تقديم نموذج إجرائى لنموذج "وين الينينج" الاستقصائى - باعتباره أحد نماذج التعلم

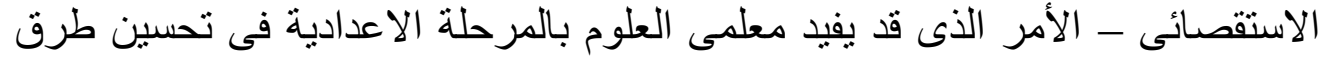

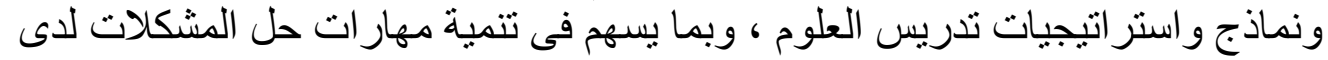

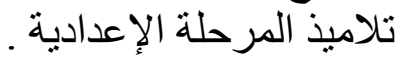
ץ. بعد استجابة لتوصيات البحوث و الدراسات و المؤتمرات التى أكدت ضرورة استخدام

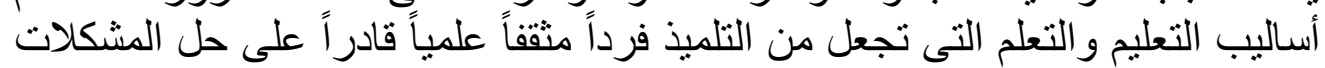

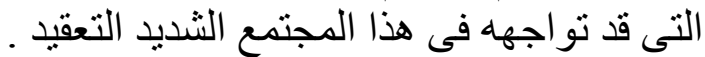

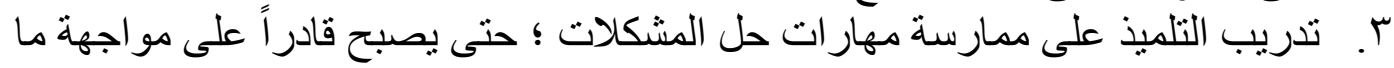

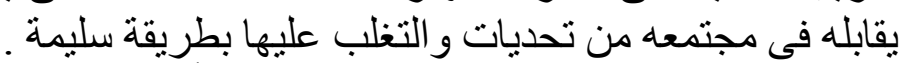

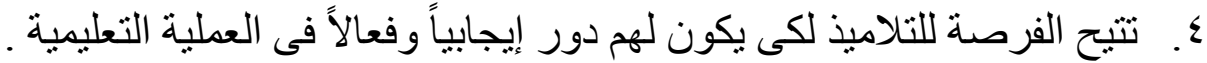

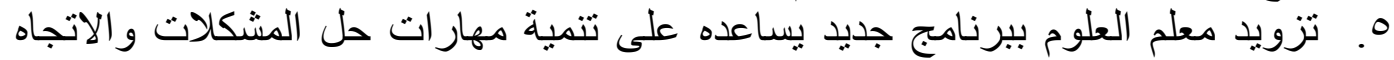

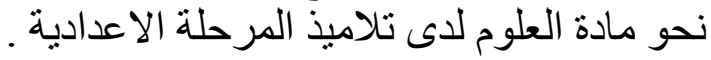

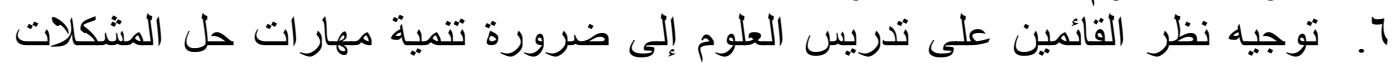

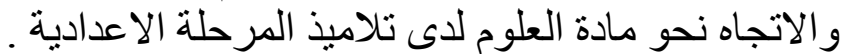

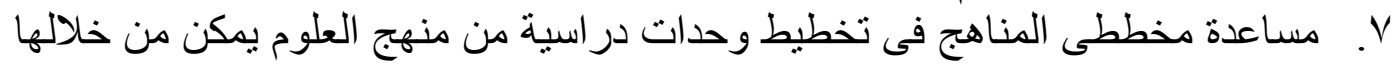

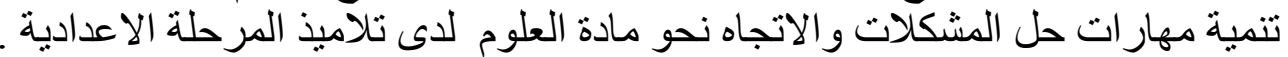




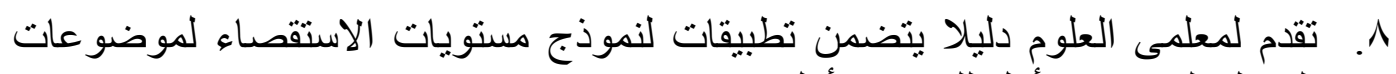

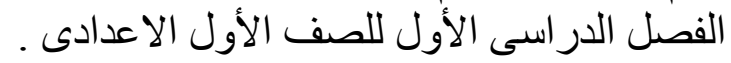

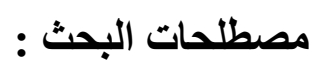

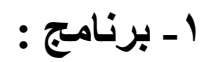

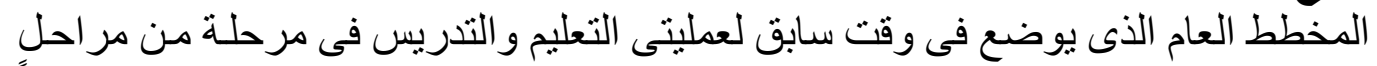

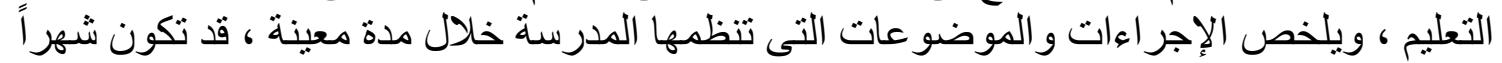

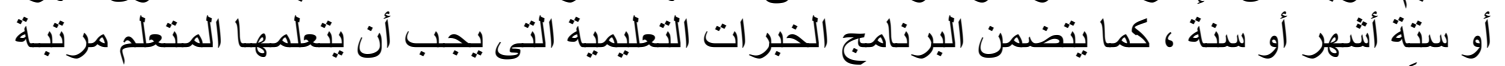

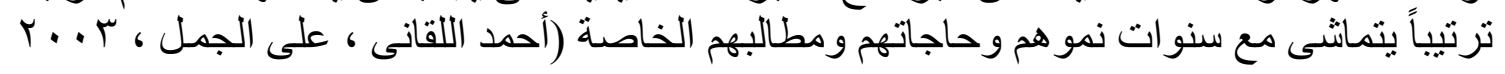

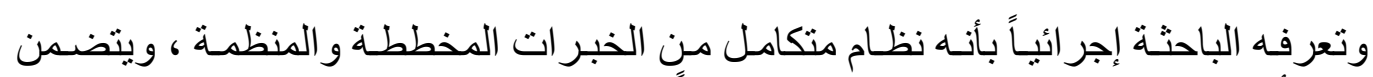

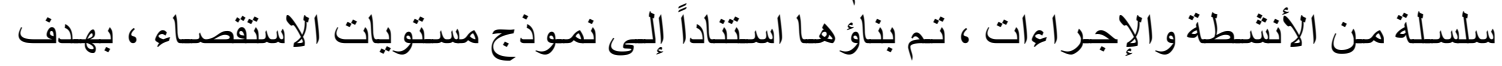

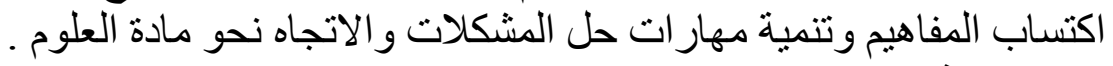

\section{r اكي}

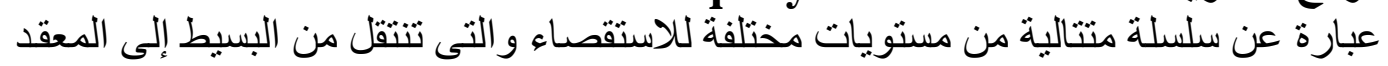

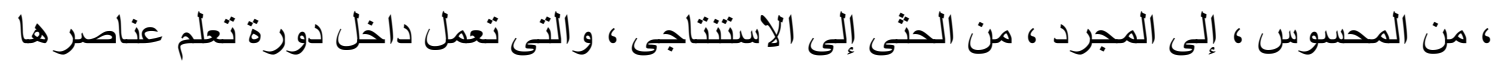

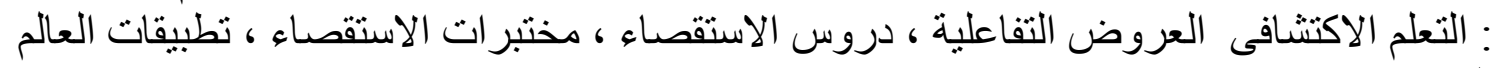

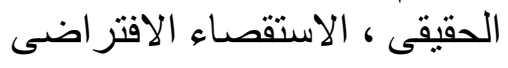

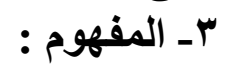

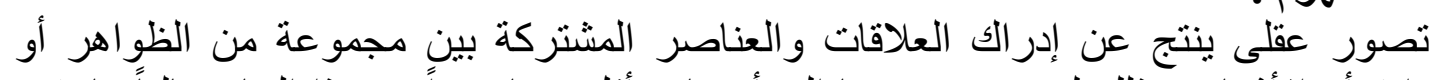

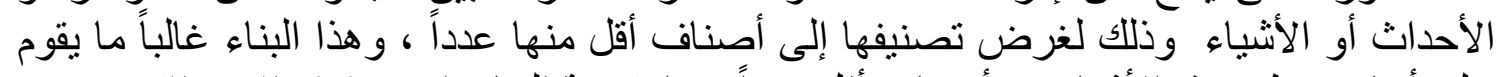

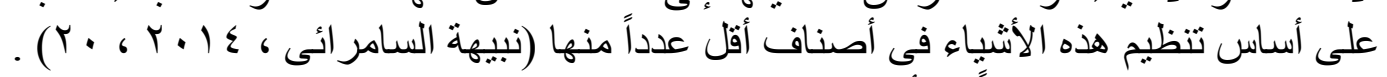

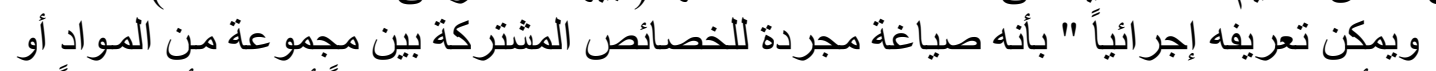

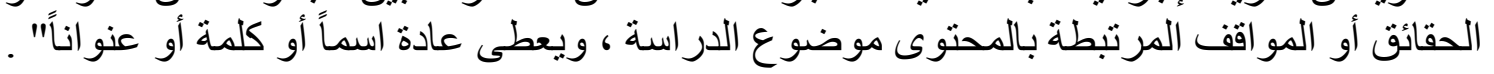

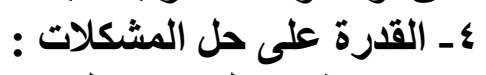

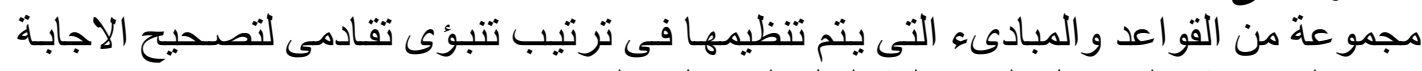

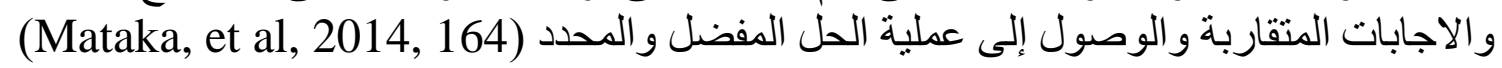

و وتعرفه الباحثة إجر ائياً بأنه : "عملية عقلية يقوم بها المتعلم وتعتمد على إثارة بعض المشكات الثكلات

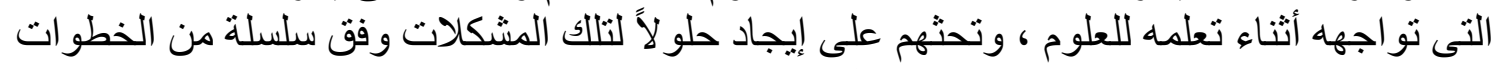

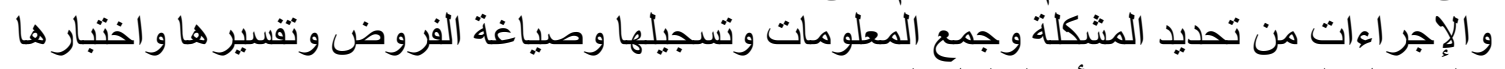

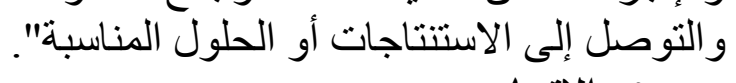

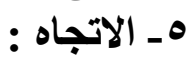

تعريف Allport للإتجاه بأنه إحدى حالات التهيؤ و التأهب العقلى العصبى التى تنظمها الخبرة

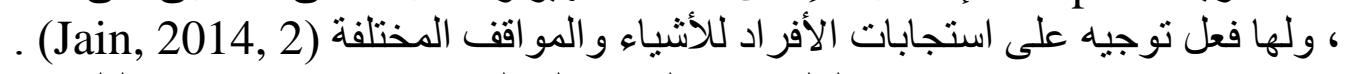

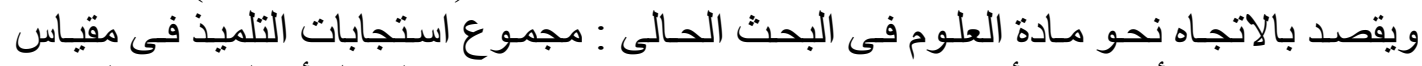

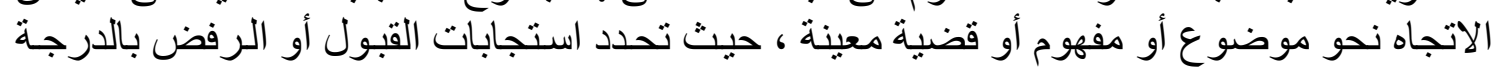

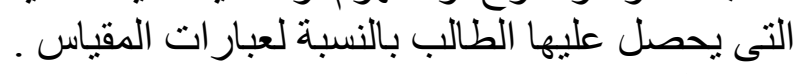
حدود البحث :

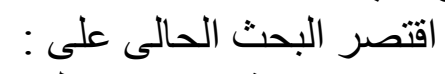

1. مجموعة من تلاميذ الصف الثانى الاعدادى فى مدرسة بr يوليو الإعدادية المشتركة 
r. موضو عات الفصل الدر اسى التانى (الحركة الدورية ـ الصوت و والضوء ـ ـ التكاثر

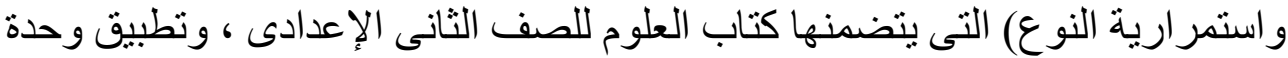

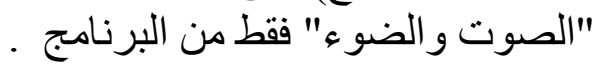

r. اكتساب المفاهيم العلمية عند المستويات المعرفية لتصنيف بلوم (تذكر - فهم - تطبيق -

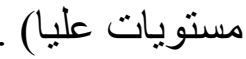

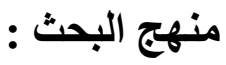

اعتمد البحث الحالى على المنهج الوصفى فى بعض مراحل الدراسة (عرض الإطار

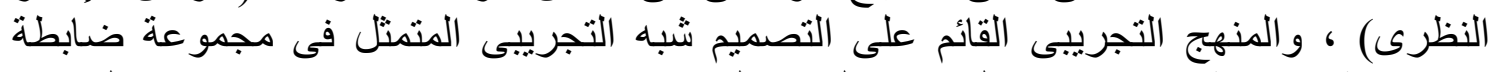

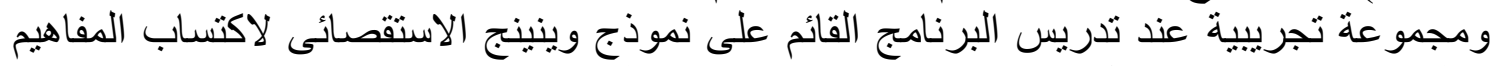

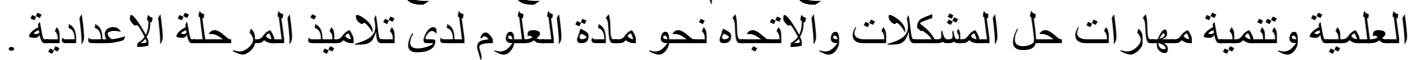
أدوات البحث : البعئ :

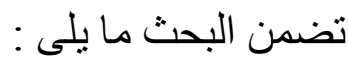
ا ـ أدو ات قياس المتغير ات التابعة : التابعة ، وشملت :

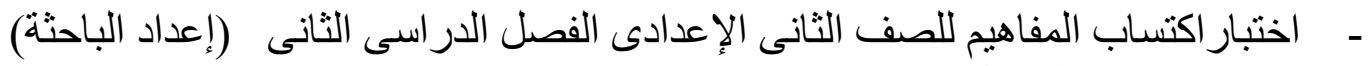
(إعداد الباحثة) (إعداد الباحثة)

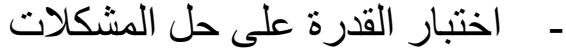

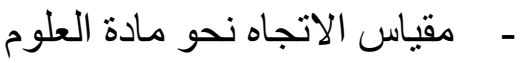
(إعداد الباحثة)

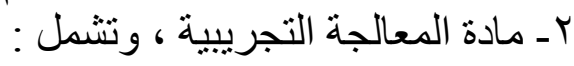

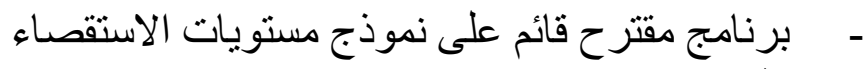
إجراعات البحث : البرج :

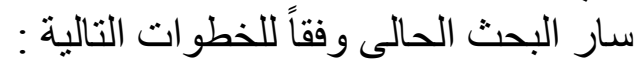

'. الإطلاع على أدبيات البحث التربوى المتصلة بموضوع البحث الحاد الحالى ، و الاستفادة منها

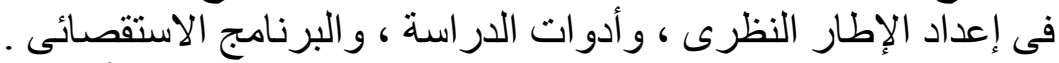

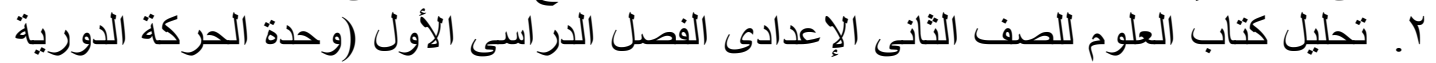

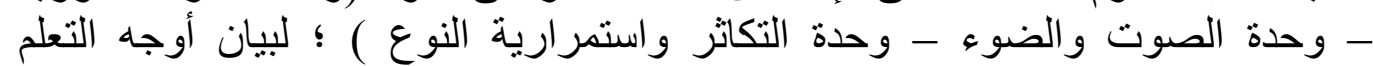

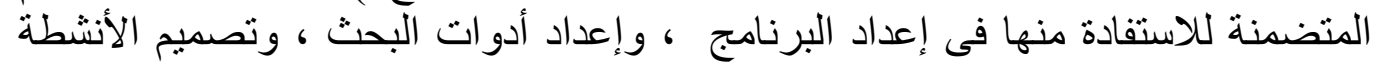

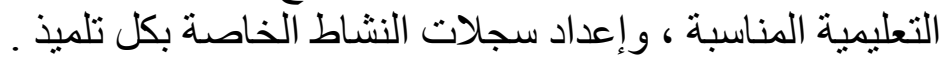

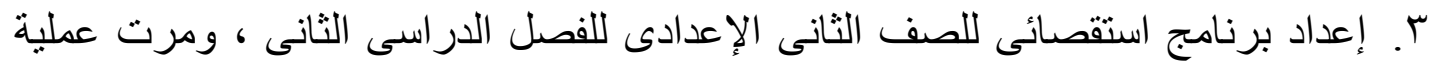

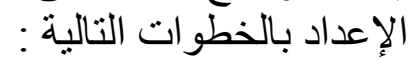

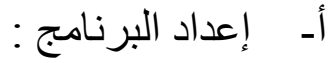

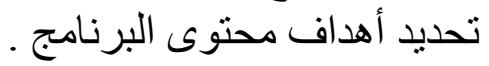

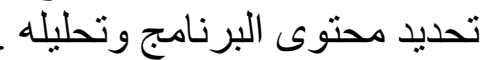

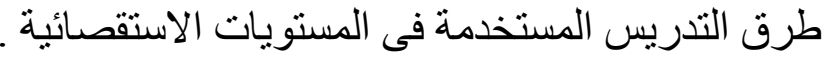

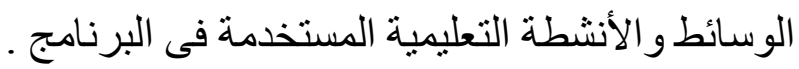
أساليب التقويم .

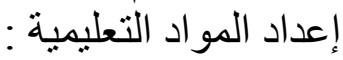

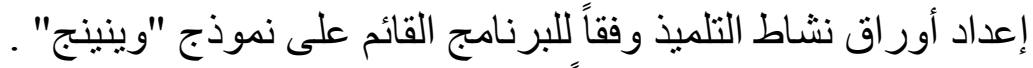

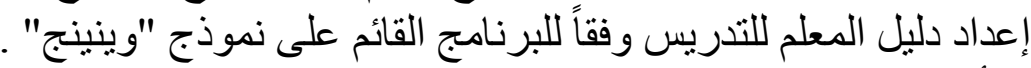

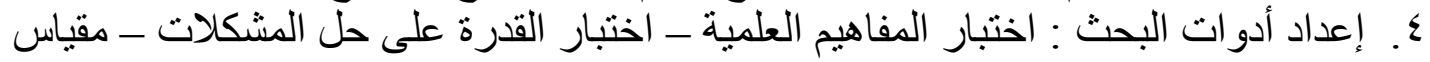

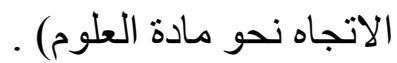

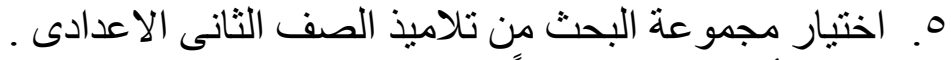
7 7. تطبيق أدوات البحث قبلياً على مجمو عة البحث . 


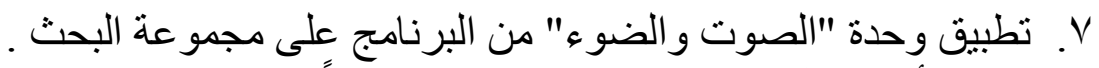

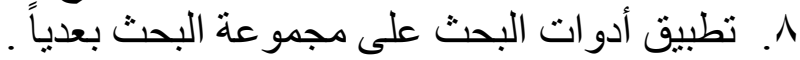

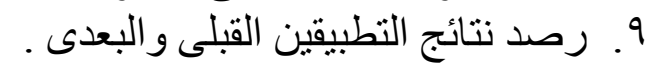
• 1. إجر اء التحليل الإحصائى وتفسير النتائج ومناقتنها ومعالجتها إحصائياً فى ضوء فروض

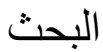
11. أتقديم التوصيات و المقترحات فى ضوء ما تسفر عنه نتائج البحث . إجراءات البحث

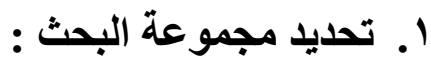

تم اختيار مجموعة البحث من تلميذات الصف الثئ الثانى الإعدادى الفترة الصباحية بنات بمدرسة بار يوليو الإعدادية المشتركة التابعة لإدارة الخانكة التعليمية بمحافظة القليوة الإنية

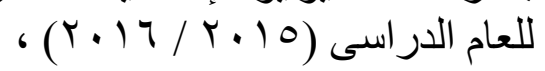

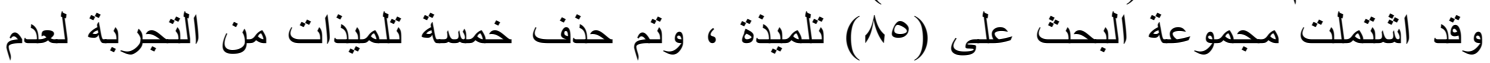

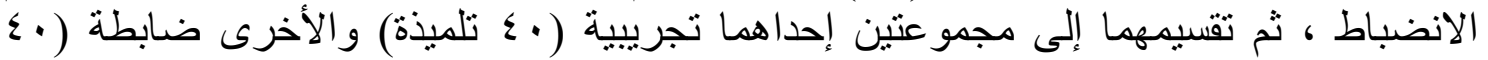

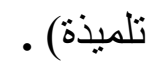

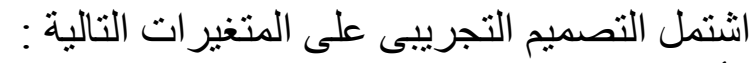

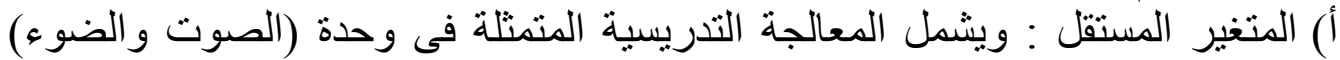

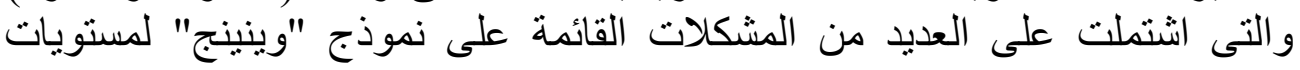
الاستقصاء.

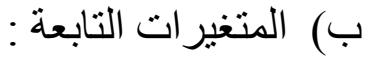

" إكتساب المفاهيم العلمية : نم قياسها عن طريق اختبار اكتساب المفاهيم العلمية

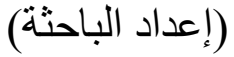

القدرة على حل المشكلات : تم قياسها عن طريق اختبار القدرة على حل المشكلات

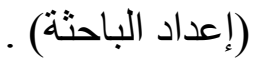

الاتجاه نحو مادة العلوم : نم قياسه عن طريق مقياس الاتجاه نحو مادة العلوم

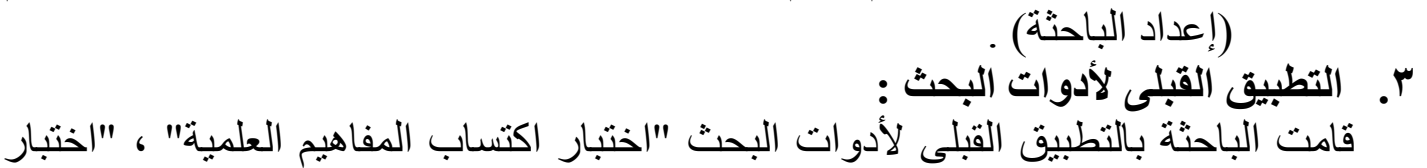

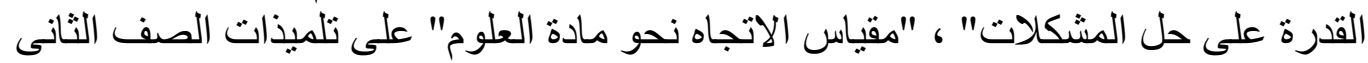

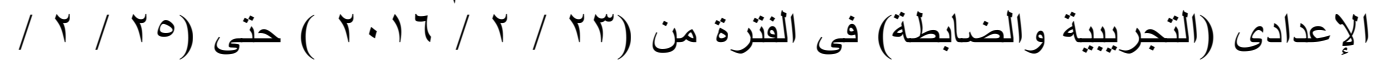
( ( تبين من التطبيق القبلى أنه لا توجد فروق ذات دلالة احصائية بين متوسطى المجموعتين

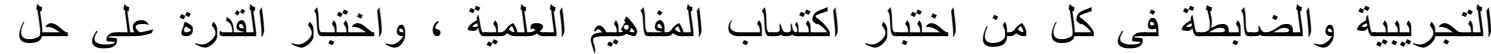

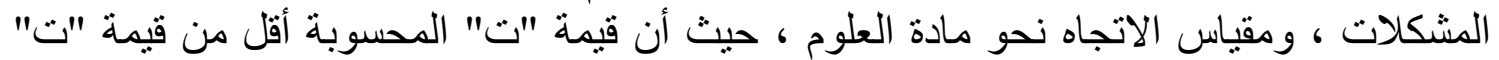

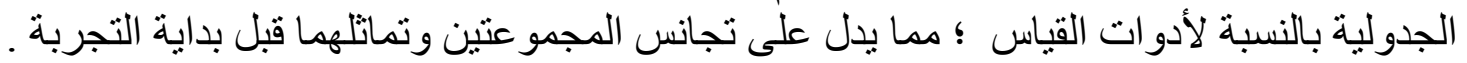

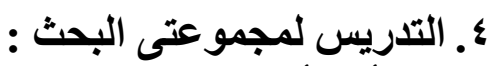

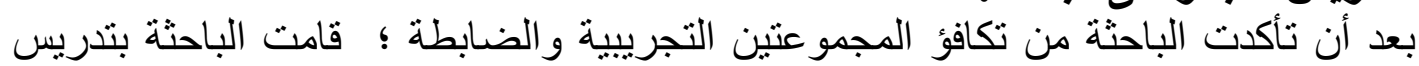

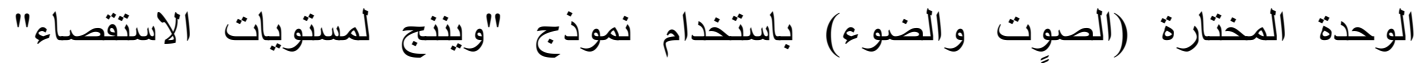

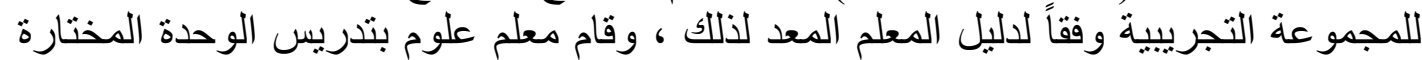

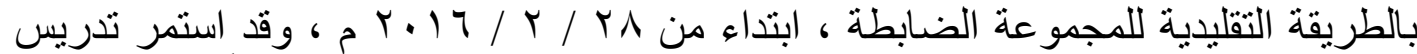

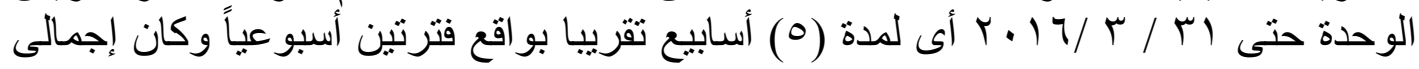


الفتر ات خلال هذه الفترة (• () فترات وهى المدة الزمنية الفعلية لتدريس الوحدة "كما هو

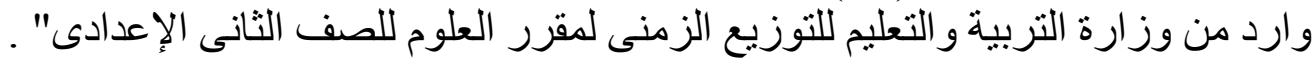

$$
\text { ๑ـ التطبيق البعدى لأدوات البحث }
$$

بعد الانتهاء من تدريس الوحدة المختارة ، قامت الباحثة بتطبيق أدوات القياس البعدى على

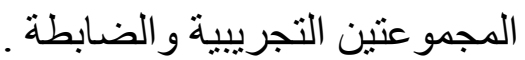
عرض النتائج ومناقشتنها :

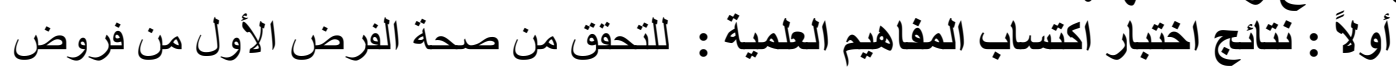

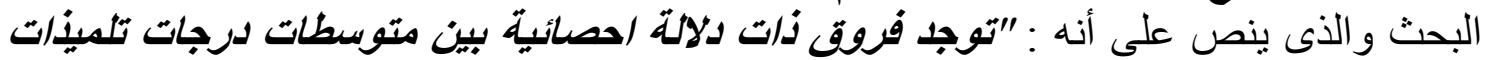

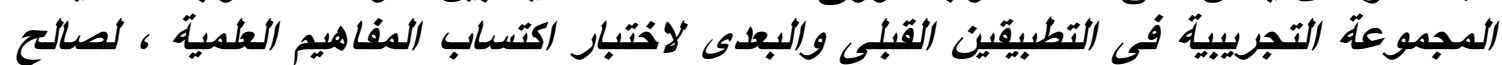
التطبيق البعدى" ، قامت الباحثة باستخدام برنامج SPSS (إصدار \& ؟) لحساب المتوسطات

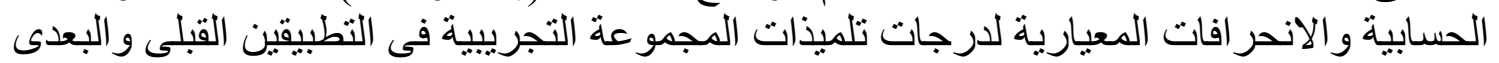

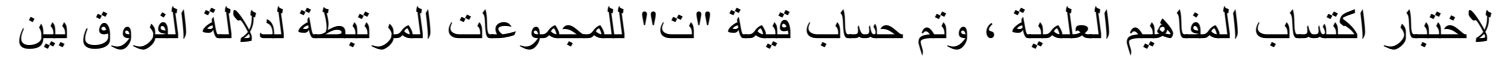

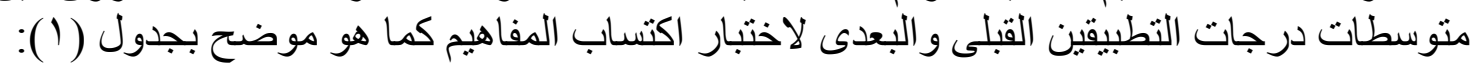

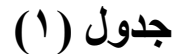

المتوسطات الحسابية والاتحر افات المعيارية وقيم (ت) ومقدار حجم التأثير لنتائج التطبيقين

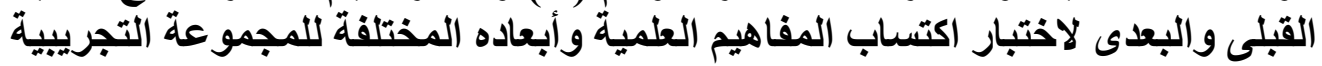

\begin{tabular}{|c|c|c|c|c|c|c|c|c|c|}
\hline \multirow{2}{*}{ التأثير } & \multirow{2}{*}{$\begin{array}{c}\text { قيم } \\
\text { ة } \\
{ }^{* *} \mathbf{d}\end{array}$} & \multirow{2}{*}{ قايتا } & \multirow{2}{*}{ قيم ت } & \multicolumn{3}{|c|}{ التطبيق البعدى } & التطبيق القبلى & \multirow{2}{*}{ الالكلية } & \multirow{2}{*}{ المستويات } \\
\hline & & & & ع & P P & $\varepsilon$ & is & & \\
\hline كبير & $\begin{array}{l}1 \cdot, \\
91\end{array}$ & $\begin{array}{l}\cdot 9 \\
7 V\end{array}$ & $\begin{array}{c}\Gamma \varepsilon, \cdot T \\
*\end{array}$ & r, rᄉ & $1 \leq, Y$. & $1, \leq 7$ & 1, Ao $^{\circ}$ & iv & تذكر \\
\hline كبير & $\begin{array}{l}11, \\
79\end{array}$ & $\begin{array}{c}\cdot 9 \\
\text { vi }\end{array}$ & $\begin{array}{c}4,07 \\
*\end{array}$ & $1, v$. & 11,01 & $\cdot, 91$ & $1,0 r$ & $1 T$ & فهم \\
\hline كبير & $1 \cdot$ & $\begin{array}{l}\cdot 9 \\
7 r\end{array}$ & $\begin{array}{c}r_{1}, \leqslant q \\
*\end{array}$ & $r, r$. & سז, & $\cdot,{ }^{\wedge} 0$ & 1,0 & 10 & تطبيق \\
\hline كبير & $\begin{array}{c}9,0 \\
r\end{array}$ & $\begin{array}{l}\cdot 9 \\
01\end{array}$ & $\begin{array}{c}r q, \gamma V \\
*\end{array}$ & o & $\wedge, \sqcap \wedge$ & $\cdot, \wedge 9$ & $1, r$ & 1. & مستويات \\
\hline كبير & $\begin{array}{l}\text { IV } \\
v V\end{array}$ & $\begin{array}{l}\cdot, 9 \\
\text { AV }\end{array}$ & $\begin{array}{c}00,71 \\
*\end{array}$ & $0, \varepsilon$. & $\leqslant 7, \leqslant 9$ & $r, 19$ & $0, \leqslant 0$ & 00 & ككل الاختبار \\
\hline
\end{tabular}

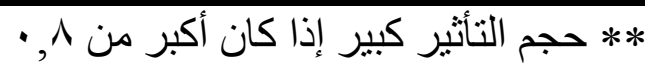

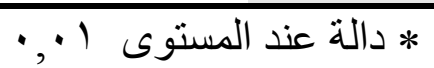

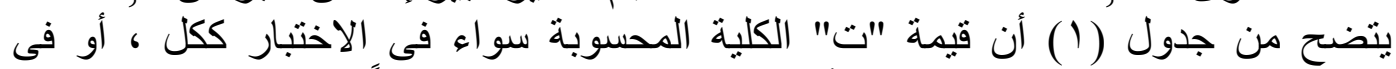

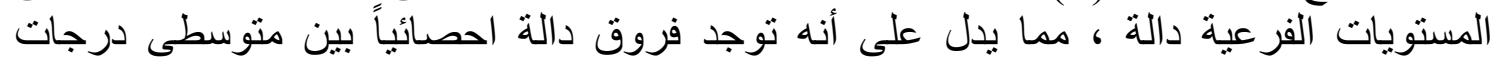


المجموعة التجريبية فى التطبيقين القبلى والبعدى لاختبار اكتساب المفاهيم العلمية لصالح التطبيق . وبالنظر إلى نتائج جدول (1) يتضح أن حجم تأثير المتغير المستقل (نموذج مستويات

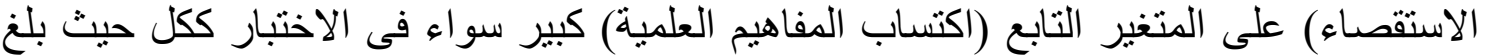
(IV,VV)

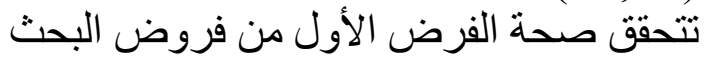

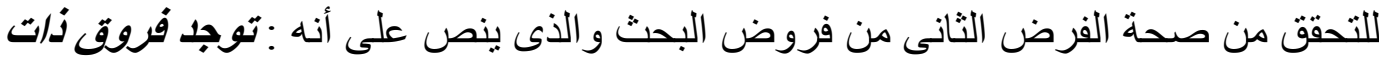

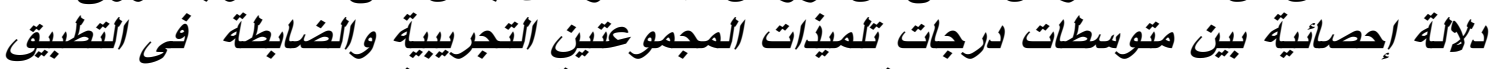

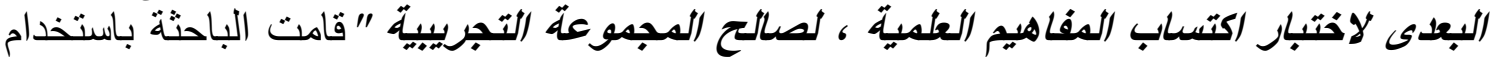
اختبار "test" لحساب دلالة الفروق بين متوسطات درجات تلميذات المجمو عتين التجريبية

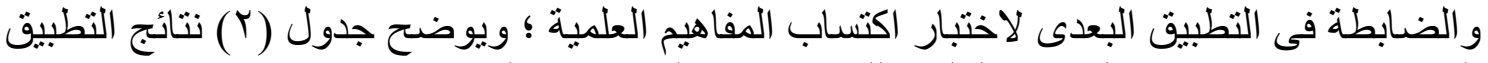

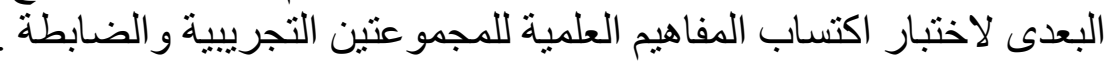

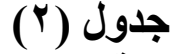

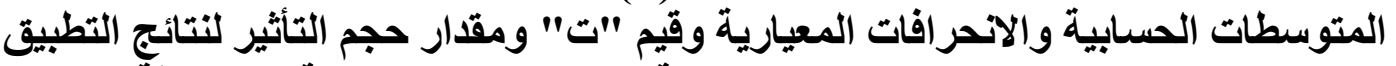

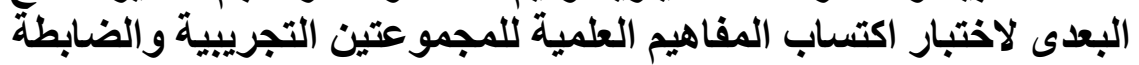

\begin{tabular}{|c|c|c|c|c|c|c|c|c|c|}
\hline \multirow{3}{*}{ التأثير } & & \multirow{3}{*}{ قيمة } & & $(\xi \cdot=$ & ن أ =ن & & & & \\
\hline & \multirow{2}{*}{ قيمة } & & \multirow{2}{*}{ قيم ت } & \multicolumn{2}{|c|}{ ضــــــة } & \multicolumn{2}{|c|}{ تجبريبية } & \multirow{2}{*}{ الكلية } & \multirow{2}{*}{ المستويات } \\
\hline & & & & $\varepsilon$ & 4 & $\varepsilon$ & is & & \\
\hline كبير & $r, \wedge$ & $\cdot, 779$ & $*$ Ir,00 & $1, r \vee \Lambda$ & $\wedge, \wedge r$ & $r, r \wedge$ & $1 \leqslant, r$. & IV & تذكر \\
\hline كبير & $r, q$ & $\cdot, T \vee T$ & ${ }^{*}{ }_{1}, V_{T}$ & $\cdot, q \wedge r$ & $v, r$. & $1, v$. & 11,01 & ir & فهم \\
\hline كبير & $1, \varepsilon$ & סחז, & $*^{*}, Y V$ & $r, 11$ & $q, r \cdot$ & $r, r$. & Tr,T & 10 & تطبيق \\
\hline كبير & 1,1 & $\cdot, 0 . V$ & ${ }^{*} \vee, Y \varepsilon$ & $1, \leqslant 0$ & 0,90 & 1, ro & $\wedge, r \wedge$ & 1. & مستويات \\
\hline كبير & $r, q$ & $\cdot, V Y T$ & $* 1 \leqslant, r q$ & $r, \pi r$ & r & $0, \varepsilon$. & $\leq 7, \leqslant 9$ & 00 & الاختبار ككل \\
\hline
\end{tabular}

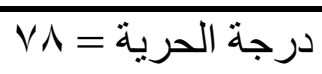

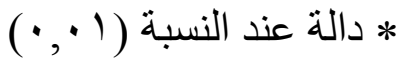

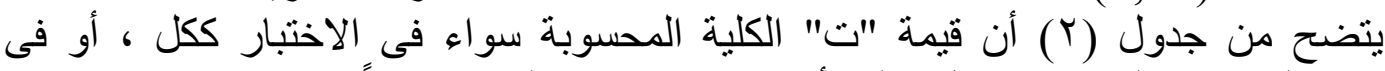

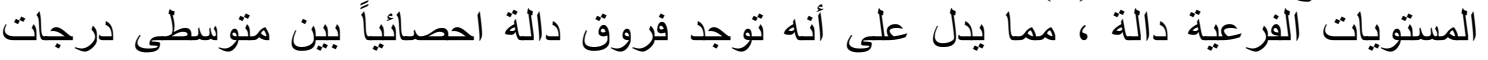

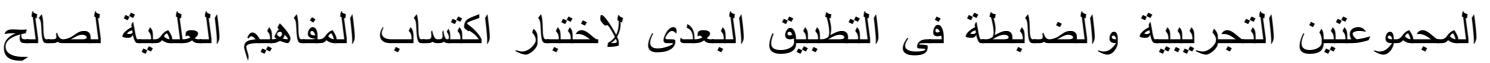

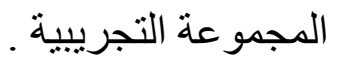

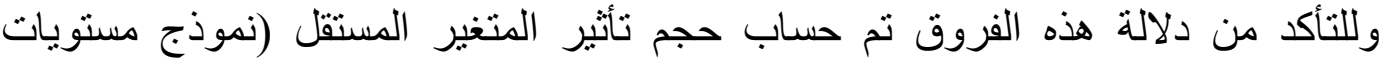

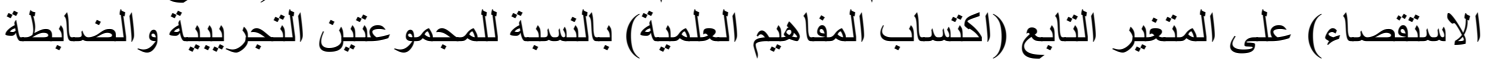

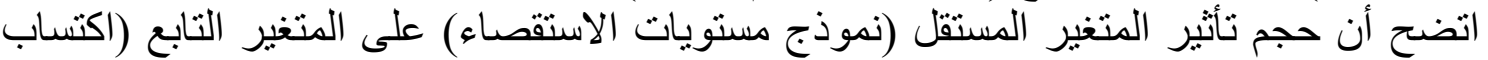

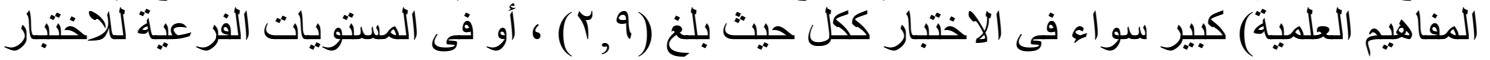

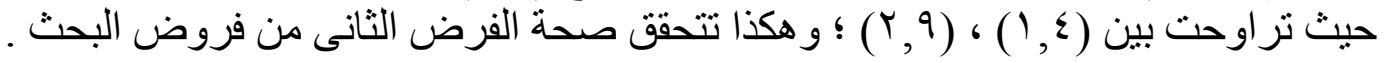


ثاتيا : نتائج تطبيق اختبار القدرة على حل المشكلات

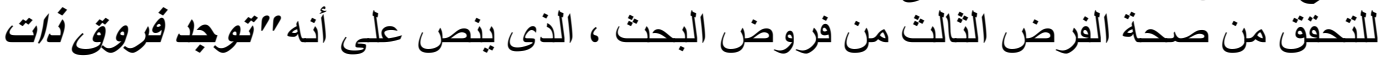

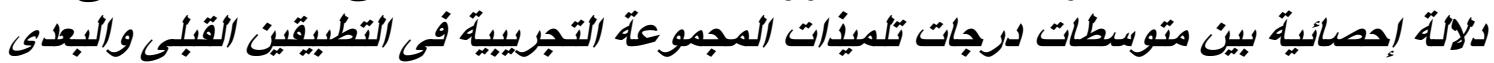

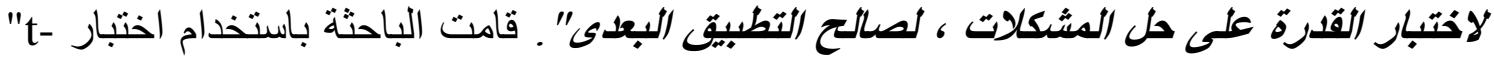

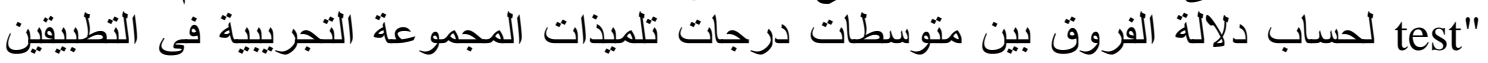

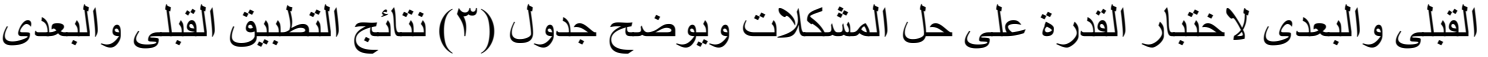

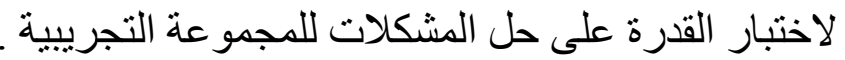

(ب) جدولة (ب)

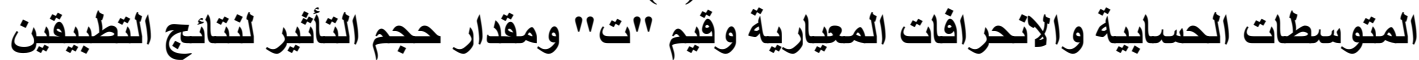

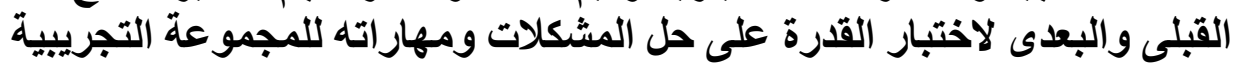

$(\varepsilon \cdot=\dot{0})$

\begin{tabular}{|c|c|c|c|c|c|c|c|c|c|}
\hline \multirow{2}{*}{ التأثجير } & \multirow{2}{*}{ قيمة d } & \multirow{2}{*}{ قيمة } & \multirow{2}{*}{ قيم ت } & \multicolumn{2}{|c|}{ التطبيق البعدى } & \multicolumn{2}{|c|}{ التطبيق القبلى } & \multirow{2}{*}{ الكلية } & \multirow{2}{*}{ المهارات } \\
\hline & & & & $\varepsilon$ & מל & $\varepsilon$ & מן & & \\
\hline كبير & $7, \leqslant 7$ & . & $\begin{array}{l}r \cdot, \\
* y\end{array}$ & 1,07 & $\vee, \wedge \wedge$ & $1, \mu \wedge$ & $r, \wedge r$ & 1. & تحديد المشكلة \\
\hline كبير & $v, \wedge)$ & $\begin{array}{c}., 94 \\
\wedge\end{array}$ & $\begin{array}{l}r \leqslant, r \\
* q\end{array}$ & $1, \varepsilon \leqslant$ & $\vee, r \wedge$ & $1, \cdot v$ & 1,94 & 1. & جمع المعلومـات \\
\hline كبير & $7, \leqslant \varepsilon$ & . & $\begin{array}{l}r \cdot, \\
* r\end{array}$ & 1,11 & 7,70 & $\cdot, \wedge \wedge$ & $1, Y \wedge$ & 1. & فرض القروض \\
\hline كبير & $1 \cdot, 2$ & $\cdot,_{0}^{97}$ & $\begin{array}{l}r, y \\
* 0\end{array}$ & $1, \leqslant 7$ & $7, r \wedge$ & $\cdot, \wedge \cdot$ & $\cdot, \vee \wedge$ & 1. & اختبار صحة \\
\hline كبير & $\vee, \wedge \vee$ & $\cdot 9$ & $\begin{array}{l}r \leq, 0 \\
* y\end{array}$ & $1, r \varepsilon$ & 7,1 . & $\cdot, \wedge \varepsilon$ & •, & 1. & استخلاص النتائج \\
\hline كبير & ${ }_{\varepsilon}{ }_{\varepsilon}, \wedge$ & $\cdot 9 V$ & $\varepsilon \cdot$, & $7, r$ & $r \varepsilon, \Gamma$ & $r, I r$ & V,T & 0. & الاختبار ككل \\
\hline
\end{tabular}

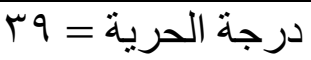

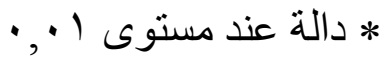

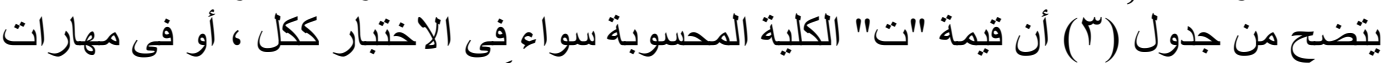

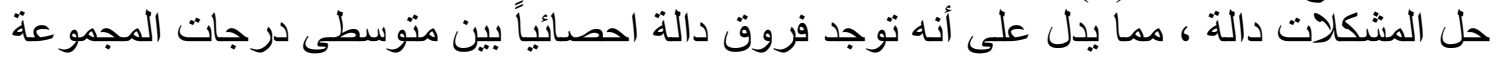

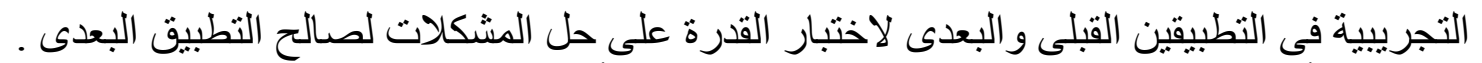

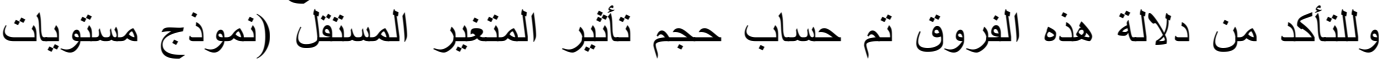

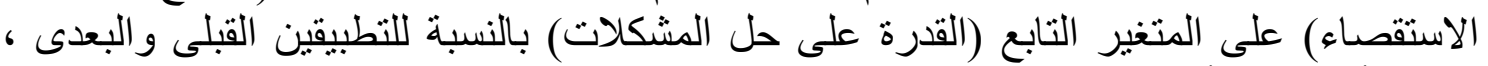

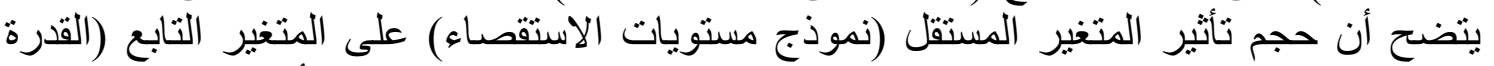

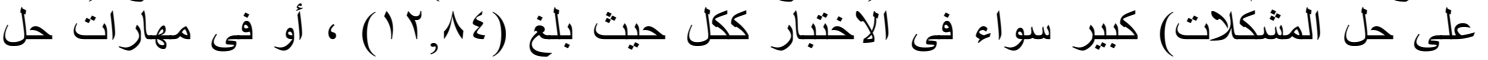

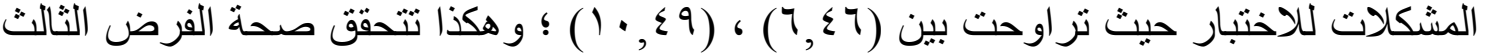

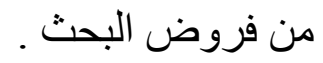
للتحقق من صحة الفرض الر ابع من فروض البحث ، لتوجد فروق ذات دلالة إحصائية بين

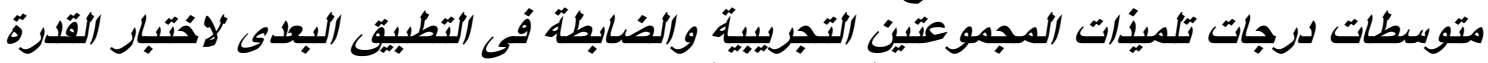

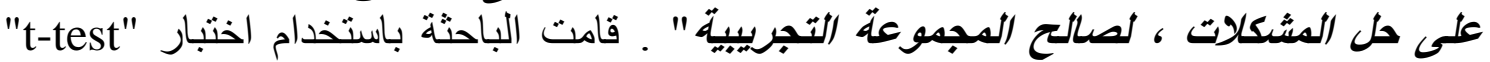
لحساب دلالة الفروق بين متوسطى درجات تلميذات المجمو عتين التجريبية والضابطة في التطية التطبيق 
البعدى لاختبار القدرة على حل المشكلات ، ويوضح جدول (ع) نتائج التطبيق البعدى لاختبار

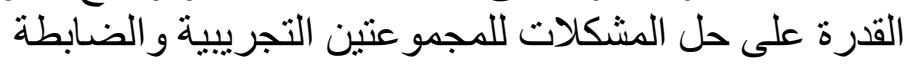

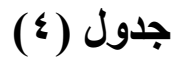

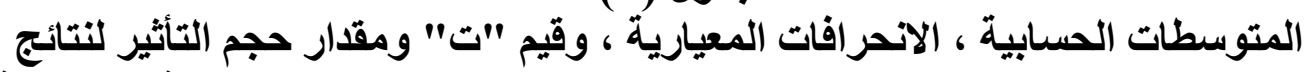
التطبيق البعدى لاختبار القدرة على حل المشكلات للمجموعتين التجريبية والضابطة التئية

$$
\text { (ن) }
$$

\begin{tabular}{|c|c|c|c|c|c|c|c|c|c|}
\hline \multirow{2}{*}{ التأثير } & \multirow{2}{*}{ قيمة } & \multirow{2}{*}{ قيمة } & \multirow{2}{*}{ قيم } & \multicolumn{4}{|c|}{ 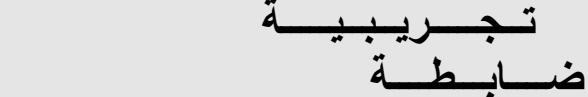 } & \multirow{2}{*}{ الالكلية } & \multirow{2}{*}{ المهارات } \\
\hline & & & & $r_{\varepsilon}$ & $r_{p}$ & $1 \varepsilon$ & p & & \\
\hline كبير & $\frac{r, q}{9}$ & $\stackrel{p}{v q}^{v q}$ & $\begin{array}{l}\text { IV, } \\
\leqslant q \\
*\end{array}$ & $1, r V$ & $r, r r$ & 1,07 & $\vee, \wedge \wedge$ & 1. & تحديد المشكلة \\
\hline كبير & r,q & •, vq & $\begin{array}{l}\text { IV, } \\
r r \\
*\end{array}$ & $1, r \mu$ & $r, \cdot r$ & $1, \leqslant \leq$ & $\vee, r \wedge$ & 1. & جمع المعلومـات \\
\hline كبير & r, & • & $\begin{array}{l}1 \leqslant, \\
* \\
*\end{array}$ & $1, r \leqslant$ & $1, \leqslant 0$ & 1,11 & 7,70 & 1. & فرض الفروض \\
\hline كبير & $r_{0}^{r, v}$ & $\cdot \stackrel{, V V}{q}$ & $\begin{array}{l}\text { 17, } \\
\text { ov } \\
*\end{array}$ & 1,19 & $1, \leqslant \mu$ & $1, \leqslant 4$ & $7, \mathrm{r} \wedge$ & 1. & الفتبار صحة \\
\hline كبير & r, & $\stackrel{\cdot, \mathrm{VV}}{\varepsilon}$ & $\begin{array}{l}17, \\
47 \\
*\end{array}$ & $1, Y r$ & $1, \leqslant \mu$ & $1, r \leq$ & $7,1$. & 1. & استخلاص النتائج \\
\hline كبير كبر & 0,0 & •, & $\begin{array}{l}r \leqslant, \\
\text { or } \\
*\end{array}$ & $r, v v$ & 1,70 & $7, \cdot r$ & $r \varepsilon, r \wedge$ & o. & الاختبار ككل \\
\hline
\end{tabular}

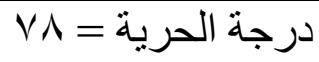

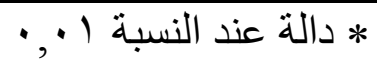

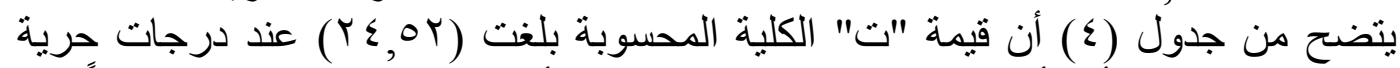

(VN) ودلالتها ( (VN)

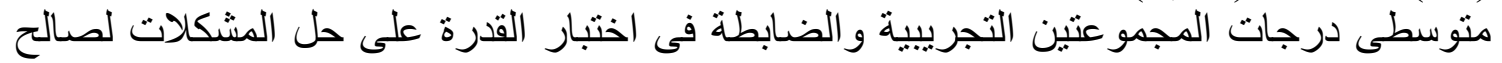

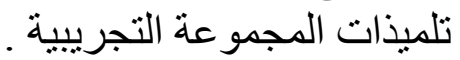

وللتأكد من دلالة هذه الفروق نم حساب حجم تأثير المتغير المستقل (نموذج مستويات

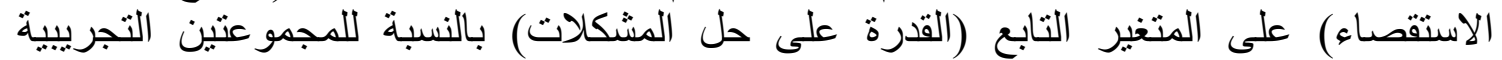

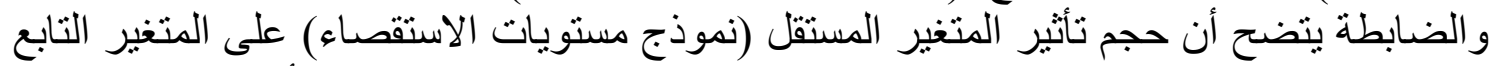

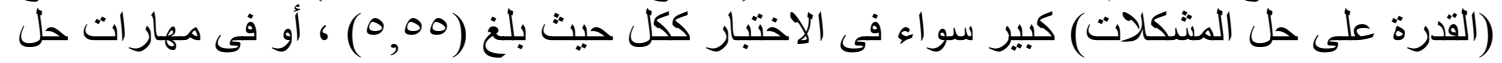

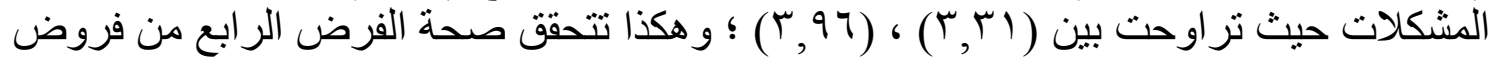


ثالثاً : نتائج تطبيق مقياس الاتجاه نحو مادة العلوم :

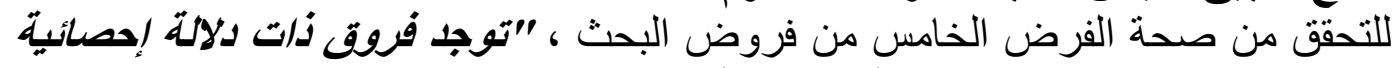

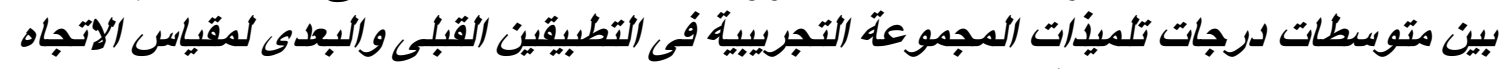

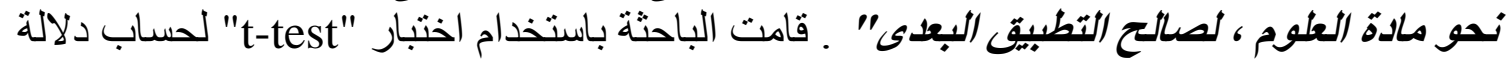

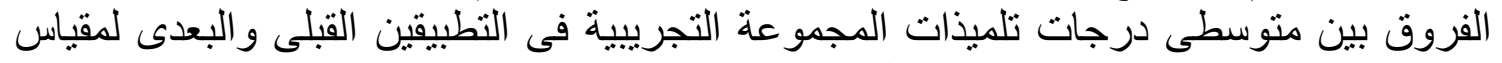

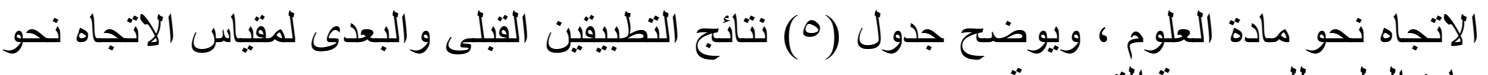

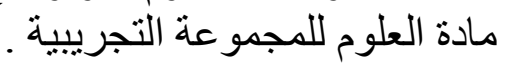

\section{جدول(0)}

المتوسطات والانحرافات المعيارية وقيم "ت" ومقدار حجم التأثير فى التطبيقين القبلى والبعدى التحو

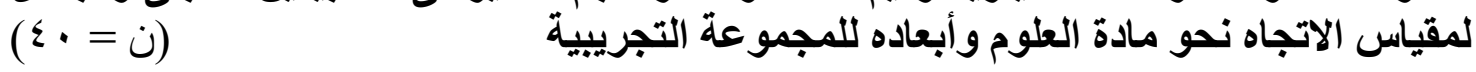

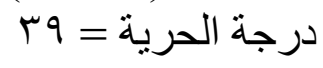

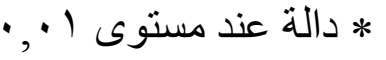

\begin{tabular}{|c|c|c|c|c|c|c|c|c|c|}
\hline \multirow{2}{*}{ التأثخٍ } & \multirow{2}{*}{ قيمة d } & \multirow{2}{*}{ قيمة } & \multirow{2}{*}{ قيم ت } & \multicolumn{2}{|c|}{ التطبيق البعدى } & \multicolumn{2}{|c|}{ التطبيث القبلى } & \multirow[t]{2}{*}{ الدر } & \multirow{2}{*}{ الأبــــــــاد } \\
\hline & & & & ع. & קמי & $\varepsilon$ & קp & & \\
\hline كبير & $0, \leqslant 7$ & $\cdot, \wedge \wedge$. & $* 1 V, \cdot 7$ & $r, 90$ & $\varepsilon \cdot, O V$ & $\varepsilon, \vee \leqslant$ & $r \cdot, r$ & $\leqslant 0$ & الالاهتمام \\
\hline كبير & $V, \cdot r$ & $\cdot, 9 r_{0}$ & $* r 1,9 r$ & $r, q 1$ & $\varepsilon \leqslant, \wedge 0$ & $\varepsilon, \leqslant 7$ & T, & $\varepsilon \wedge$ & القيمة النفعية \\
\hline كبير & $V, r r$ & -, $94 q$ & *Yr,or & $1, \leqslant 7$ & ro, $7 r$ & $r, V r$ & $17, V$ & rV & دور معلم \\
\hline كبير & $1 \cdot, \cdot 7$ & $\cdot, 971$ & *T, & $\varepsilon, \wedge 9$ & 111, & $v, \lambda r$ & $\Lambda \cdot, v$ & IT. & المقياس ككل \\
\hline
\end{tabular}

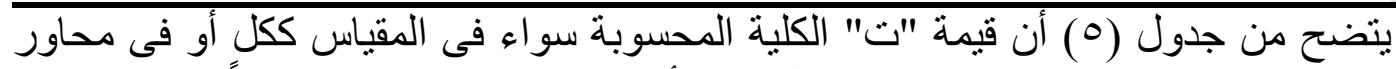

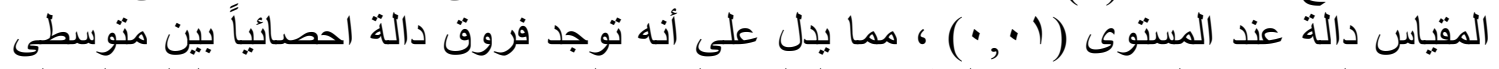

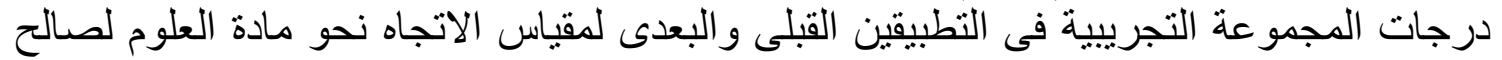

وللتأكد من دلالة هذه الفروق تم حساب حجم تأثير المتغير المستقل (نموذج مستويات

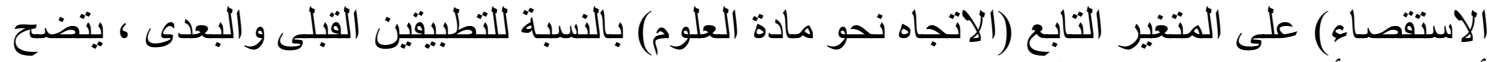

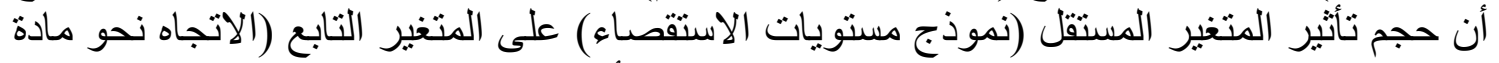

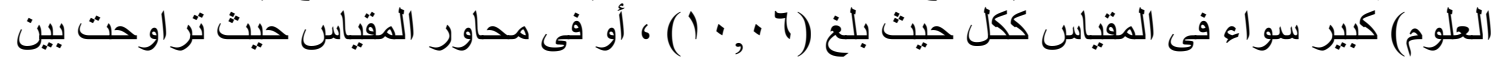

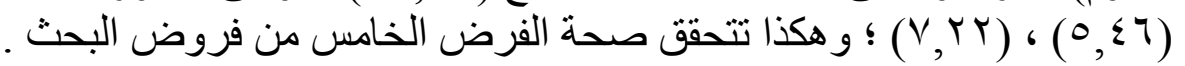

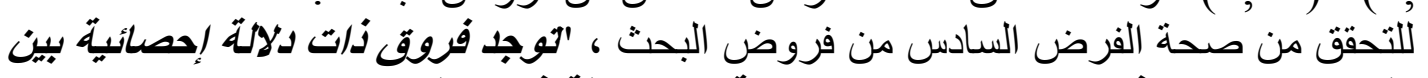

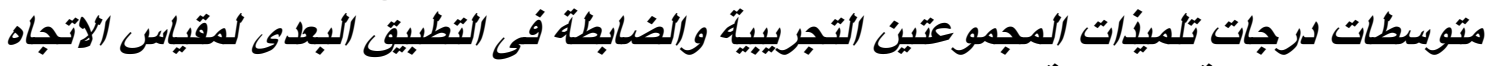

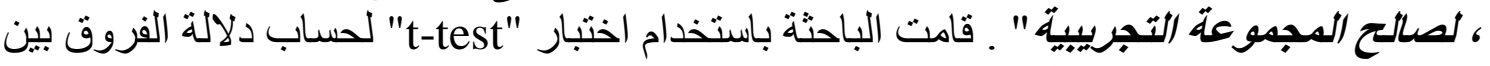

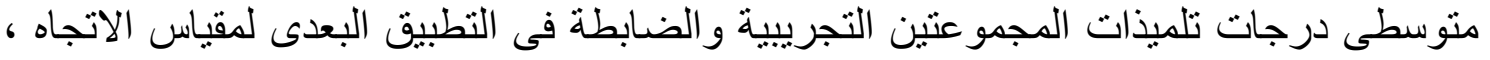

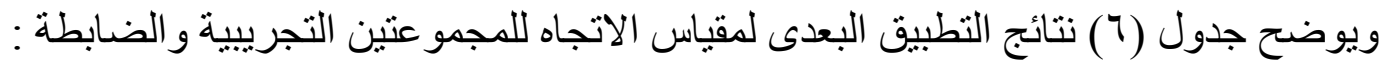




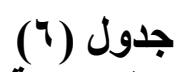

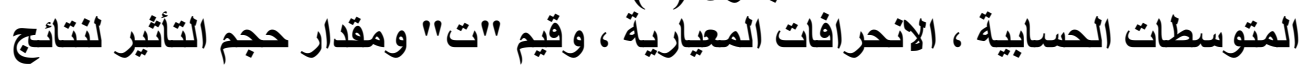
التطبيق البعدى لمقياس الاتجاه للمجموعتين التجريبية والضابطة التبطة

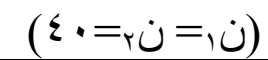

\begin{tabular}{|c|c|c|c|c|c|c|c|c|c|}
\hline \multirow{2}{*}{ التأثبر } & \multirow{2}{*}{ قيمة } & \multirow{2}{*}{ قيمة } & \multirow{2}{*}{ قيم ت } & \multicolumn{3}{|c|}{ ضــــابــطـــة } & تـجــــريـبـــــة & \multirow{2}{*}{ الالكلية } & \multirow{2}{*}{ أبعاد المقياس } \\
\hline & & & & ع & p & $\varepsilon$ & ip & & \\
\hline كبير & $r, r$ & $\cdot, 0$ & 1,90 & $\begin{array}{l}\varepsilon, 9 \\
\varepsilon 0\end{array}$ & $r r, \varepsilon r$ & $r, 90$ & $\varepsilon \cdot, 01$ & $\leqslant 0$ & الاهتمام بالعلوم \\
\hline كبير & $r, \cdot \tau$ & $\cdot V$ & $1 \pi, 00$ & $\begin{array}{l}\varepsilon, V \\
0 \leqslant\end{array}$ & $r r, q$. & $r, q 1$ & $\varepsilon \varepsilon, \wedge 0$ & $\varepsilon \wedge$ & الليمة النفعية \\
\hline كبير & r, ro & $\ddot{r}$ & $1 \leq, \wedge$. & $\frac{r}{4}, q$ & $1 v, 9$. & 1,27 & ro, Tr & TV & دور معلم العلوم \\
\hline كبير & $\varepsilon, \Gamma$ & $\ddot{r}$ & 11,99 & $\begin{array}{l}v, \wedge \\
79\end{array}$ & שr, & $\varepsilon, \wedge 9$ & $111, \cdot 7$ & Ir. & المقياس ككل \\
\hline
\end{tabular}

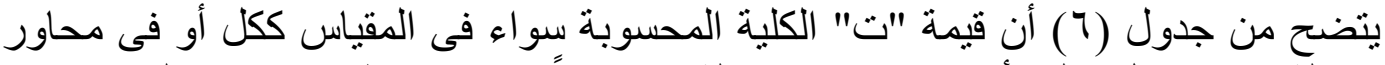

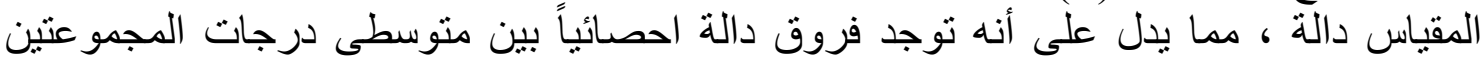

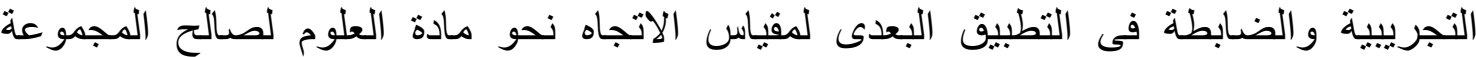

وللتأكد من دلالة هذه الفروق نم حساب حجم تأثير المتغير المستقل (نموذج مستويات التجريبية . التجرية

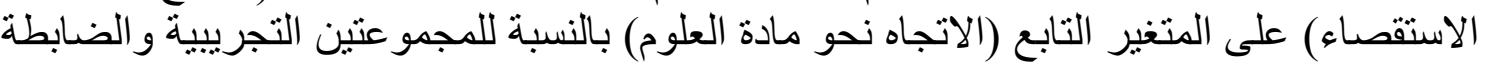

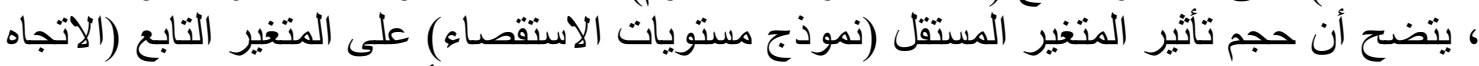

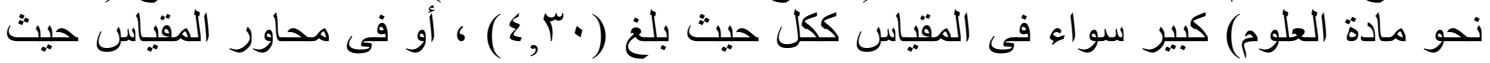

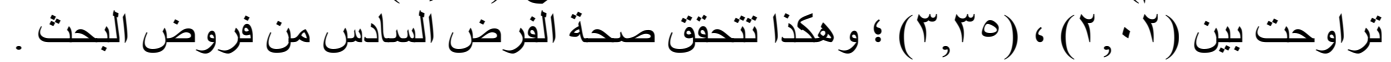

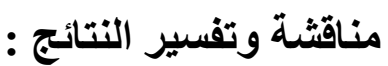

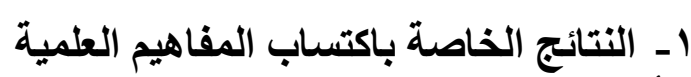

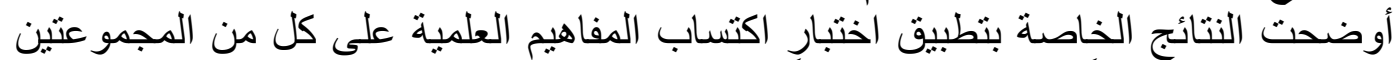

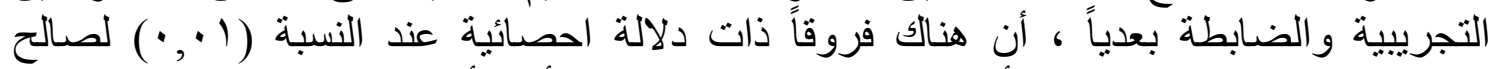

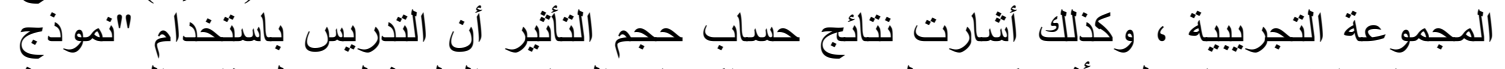

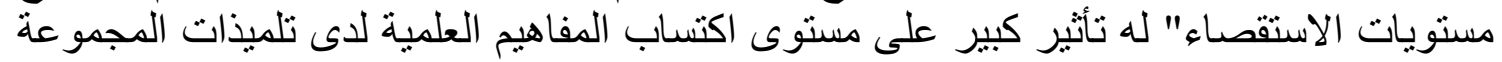

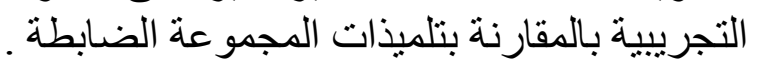

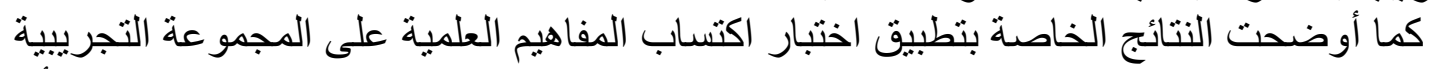

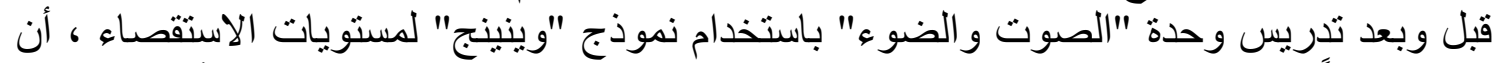

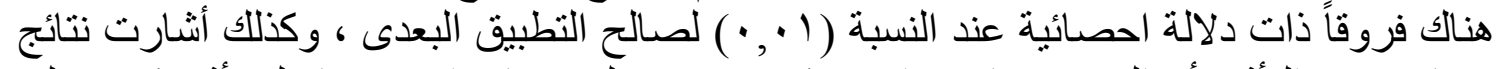

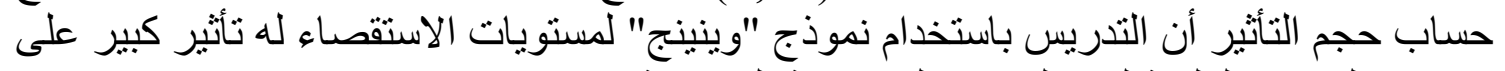

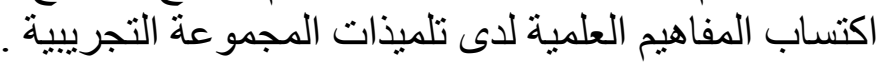

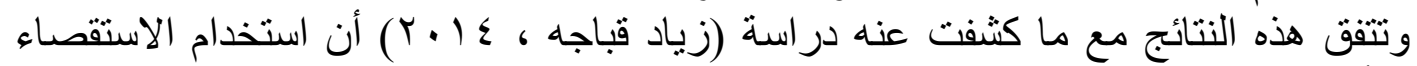

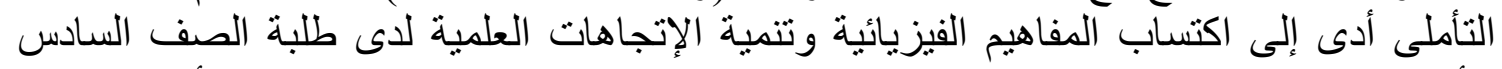

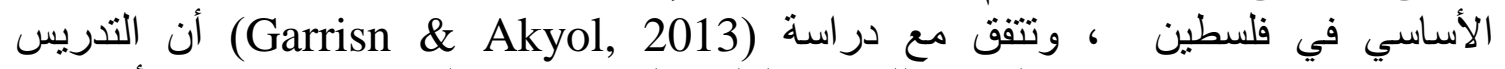
الاستقصائى يزيد من اكتساب الطلاب للمفاهيم العلمية التى تنعكس على تفكير هم ، وتتفق أيضا مع التريط 
ما توصلت إلبه دراسة (Ali Khan, et al, 2009) التى استخدمت الاستقصاء الافتر اضى وفقا لنموذج وينينج لمستويات الاستقصاء كمدخل تدريسى لتنمية المفاهيم العلمية .

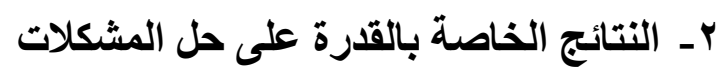

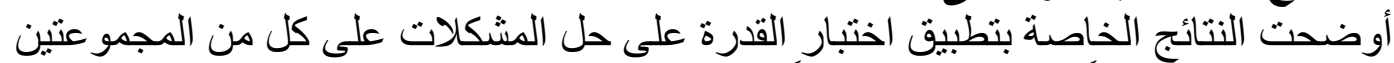

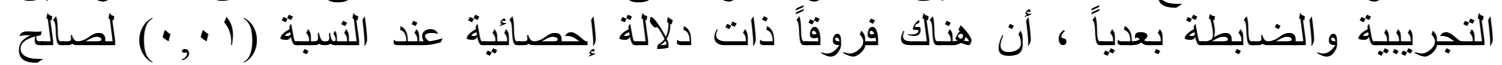

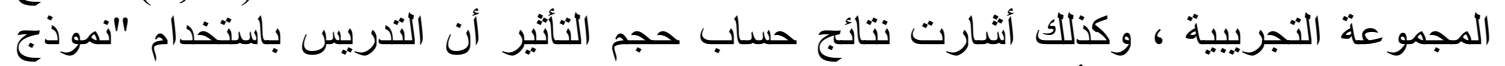

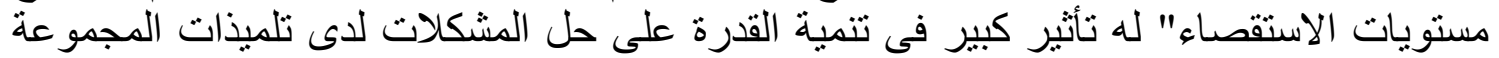

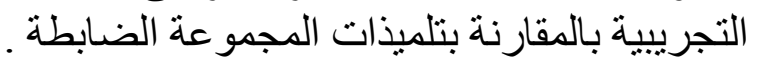
كما أوضحت النتائج الخاصة بتطبيق اختبار القدرة على حلى حل المشكلات على المديط المجموعة

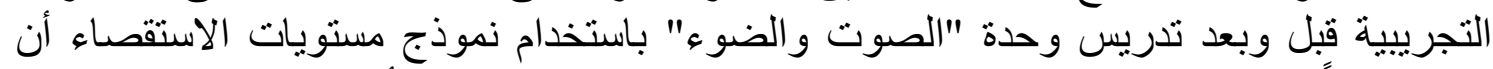

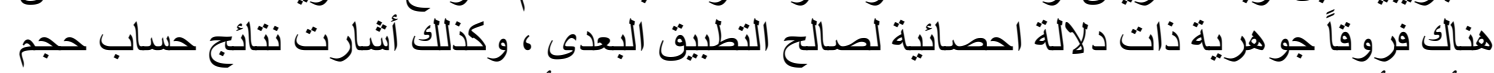

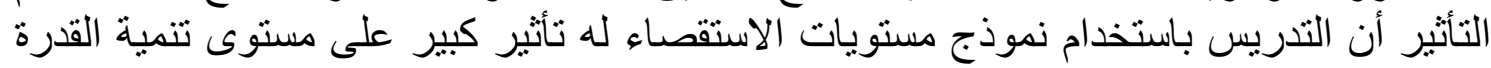

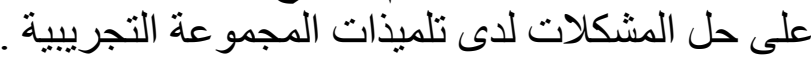

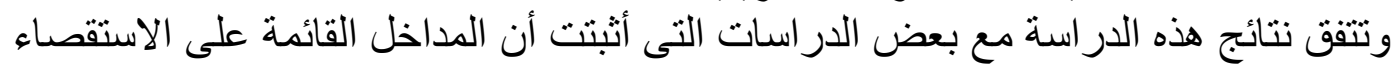

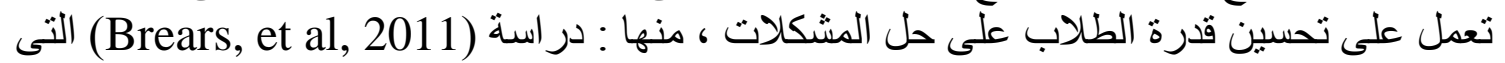
هدفت لمعرفة أثر التدريس التكاملى بين استر اتيجية التعلم المتمركز حول المشكلة ولثئ والاستقصاء

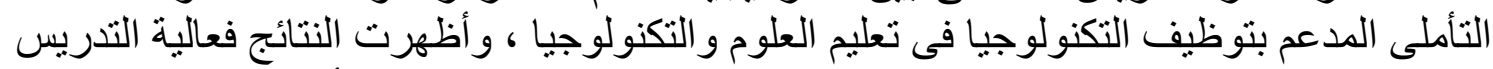

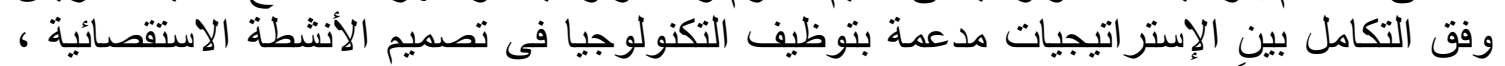

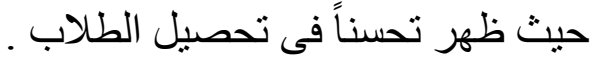
ودر اسة (Shin \& McGee, 2002) التى أكدت نتائجها أن بيئة تعلم الوسائط المتعددة

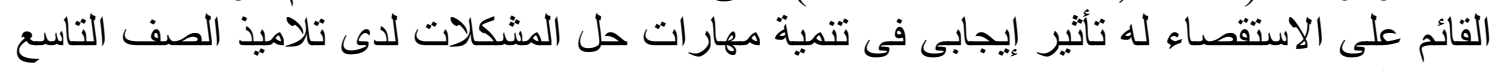
وخاصة الإناث.

\section{ا ـ النتائج الخاصة بالاتجاه نحو مادة العلوم}

توصلت نتائج البحث إلى أن استجابات معظم تلميذات المجموعة التجريبية على مقياس الاتجاه

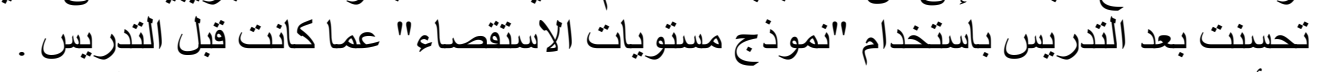

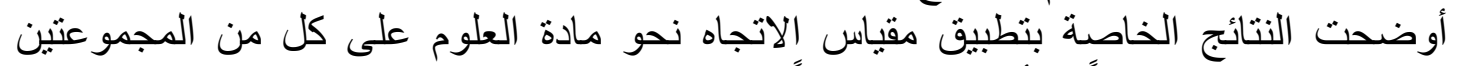

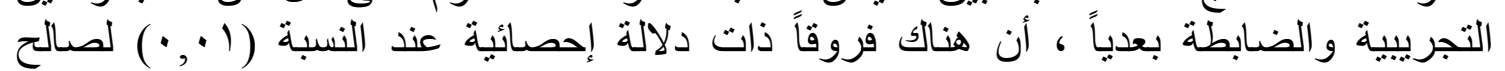

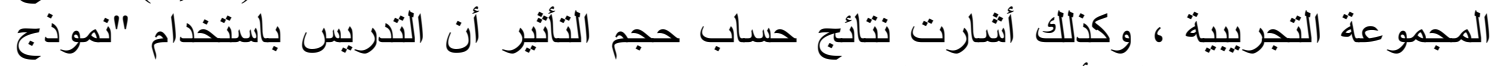

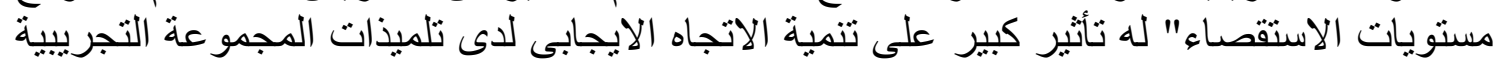

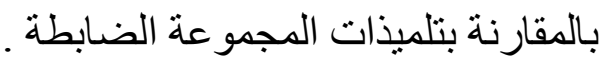

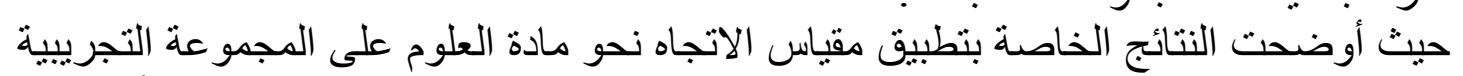

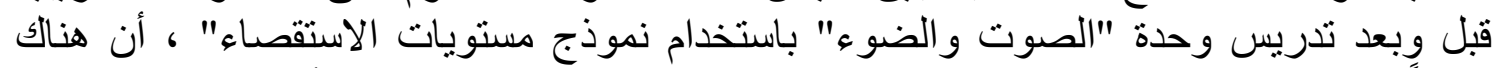

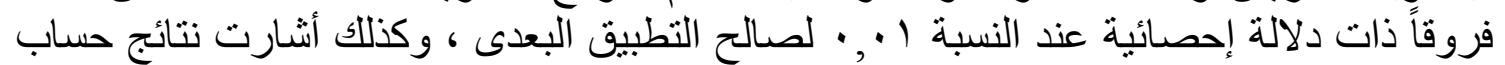

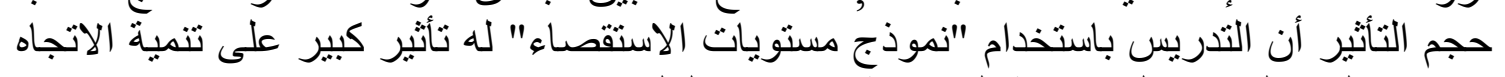

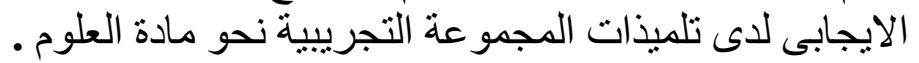
وقد اتفقت نتيجة هذا البحث مع العديد من الدراسات التى هدفت إلى التى تتمية الاتجاهات العلمية الايجابية ، منها : دراسة (Fatoke \& Olaoluwa, 2014 ) التى أكدت نتائجها على فعالية تلفية استخدام استراتيجية حل المشكلات تؤثر على اتجاهات الطلاب بإيجابية نحو تعلم الكيمياء و أيضا 


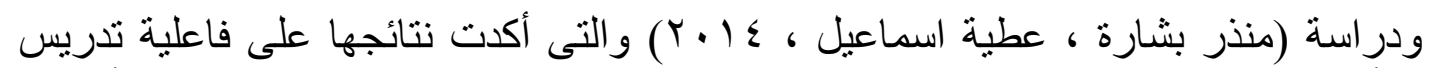

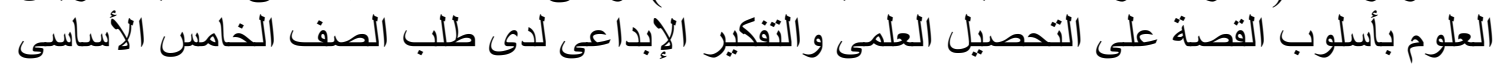

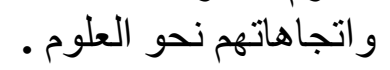

عقد دورات تدريبية وورش عمل لمعلمى العلوم فى المرحلة الإعدادية لتدريبهم على أن الن النه

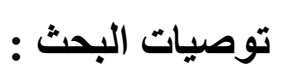

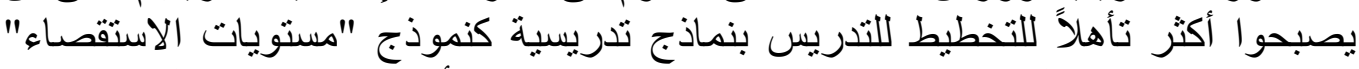

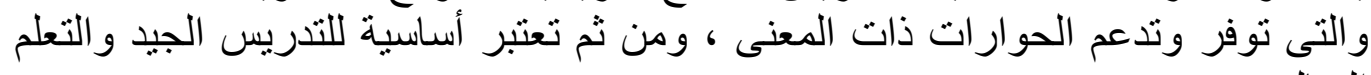

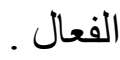

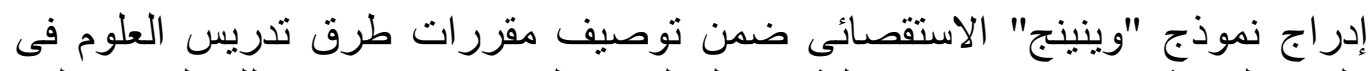

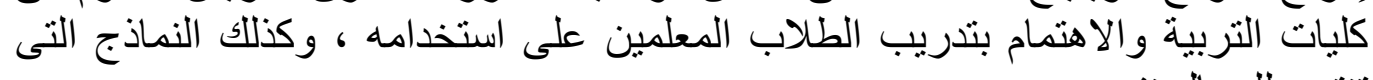

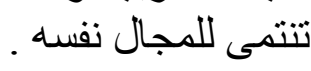

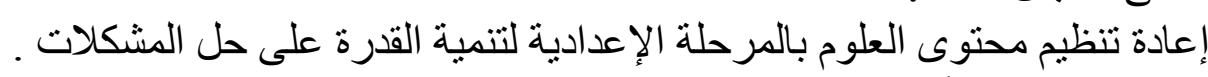

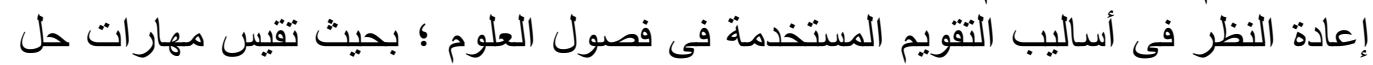

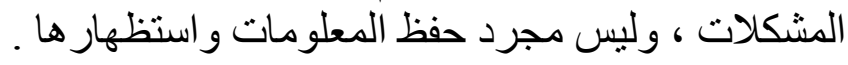

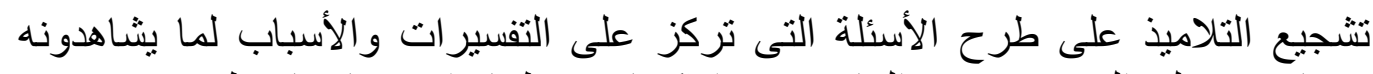

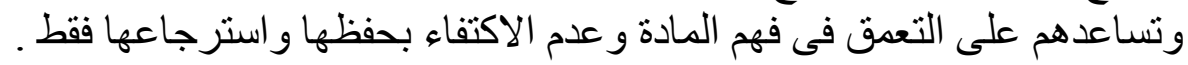

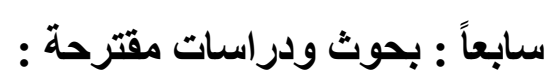

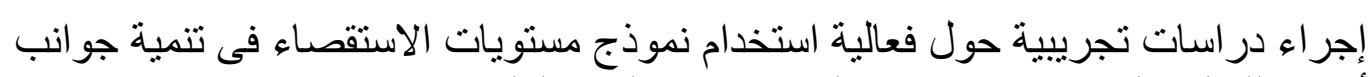

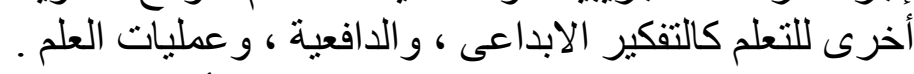

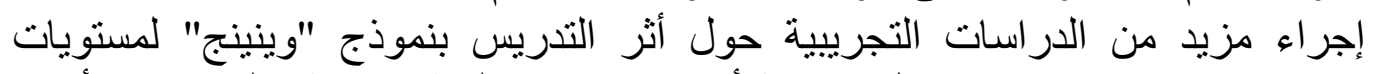

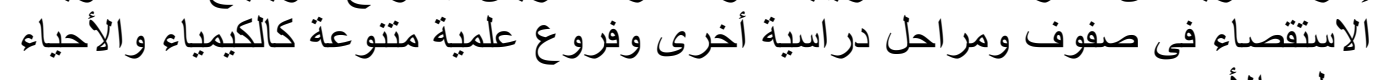

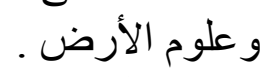
برنامج لتدريب معلمى العلوم على نموذج "وينينج" الاستقصائى ، وفاعليته فى تنمية

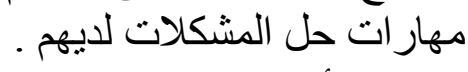
در اسة تأثير استخدام نموذج "وينينج" لمستويات الاستقصاء فى تتمية التفكير التأملى 


\section{المراجـع}

ـ ـ أحمد حسين اللقانى ، على أحمد الجمل (0 ץ) : معجم المصطلحات التربويـة المعرفة فى المنـاهج

$$
\text { وطرق التدريس ـ ط (ب) ، القاهرة ، دار الكتب . }
$$

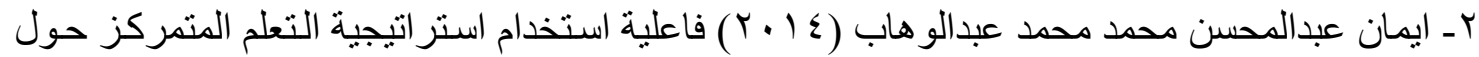
المشكلة فى تتمية مهار ات حل المشكلة فى مادة العلوم لدى تلاميذ المرحلة الإعداديـة ـ رسـالة

$$
\text { ماجستير ، كلية التربية ، جامعة بنها . }
$$

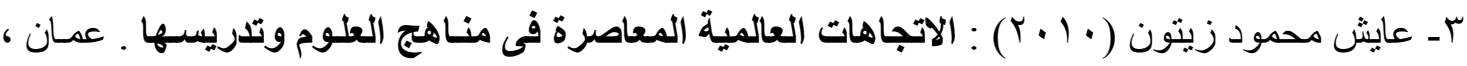

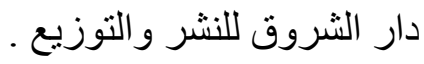

ع - عبداله محمد خطايبة (0 . . ץ) : تعليم العلوم للجميع ـ عمان ، دار المسيرة للنشر والتوزيع والطباعة

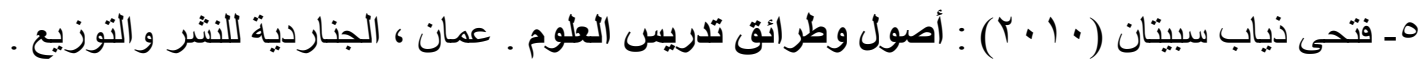

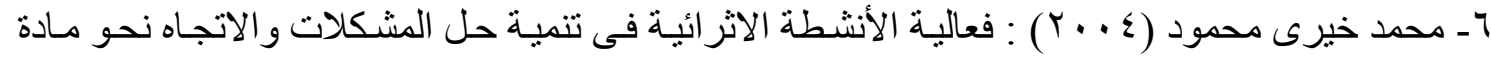
العلوم لدى تلاميذ الصف الثانى الاعدادى ـ مجلة البحث التربوى ، ع(Y) ، السنة الثالثة ،

$$
\text { . Tl }
$$

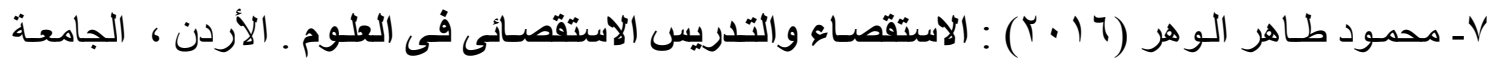
الهاشمية

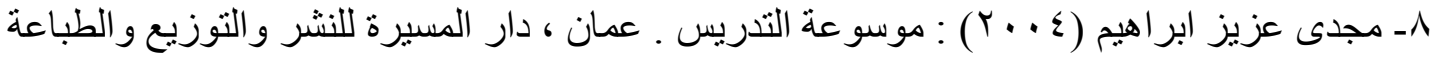

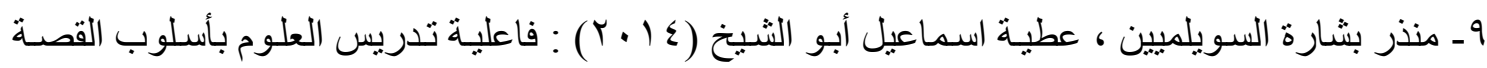
على التحصيل العلمس و التفكير الإبداعى لدى طلاب الصف الخـامس الأساسى فى العلوم

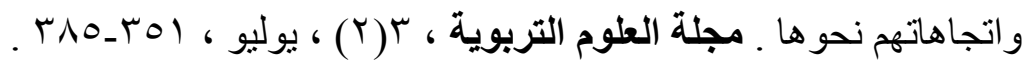

• 1 ـ منى العفيفى وآخرون (11 + ( ) : أثر استخدام دورة التقصى الثنائية فى تتمية مهار ات الاستقصاء لدى

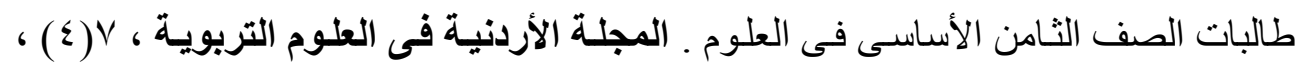
TOY_TY

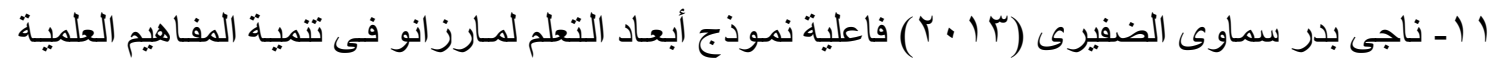
و مهار ات حل المشكلات فى مادة العلوم للى تلاميذ الصف الثامن المتوسط فى دولة الكويت . رسالة دكتور اه ، معهد الدراسات التربوية ، جامعة القاهرة .

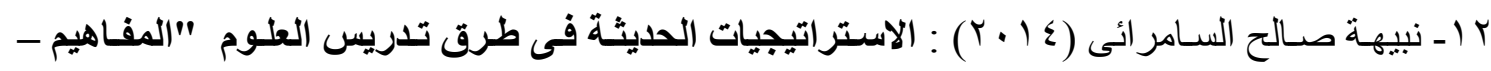
المبادى - التطبيقات" ـ عمان ، دار المناهج للنشر والتوزيع .

13- Achmad, M. \& Suhandi, A (2017) Effect of levels of inquiry model of science teaching on scientific literacy domain attitudes. AIP Conference Proceedings, 1848(1), 1-5. 
14-Ali Khan, M. (2009) Teaching of heat and temperature by hypothetical inquiry approach: A sample of inquiry teaching. Journal of Physics Teacher Education Online, 5(2), 43-64.

15- Antusova, M. \& Slepakova, I. \& Kimakova, K. (2014) Assessment of Selected biological activity based on inquiry at lower secondary.

SAILS conference (Strategies for Assessment of Inquiry Learning in Science), $24^{\text {th }}, 25^{\text {th }}$, June .

16- Dunkhase J. (2003) The Coupled - inquiry cycle: A teacher concerns - based model for effective student inquiry. Science Educator, 12(1), 10-15.

17- Etherington, M. (2011) Investigative primary science: A problem - based learning approach. Australian Journal of teacher Education, 36(9), 53- 74.

18- Fatoke, A.O. \& Olaoluwa, O.O. (2014) Enhancing students' attitude towards science through problem- solving instructional strategy. IOSR Journal of Research \& Method in Education, 4(5), ver. 11, 50-53

19- Gaigher, R (2007) Exploring the development of conceptual understandings through structured problem solving in physics. Eric (ED: 1765916).

20- Hardianti, T. \& Kuswanto, H. (2017) Difference among levels of inquiry: process skills improvement at senior high school in Indonesia. International Journal of Instruction, 10(2), 119-130.

21- Jain, V. (2014) 3D model of attitude. International Journal of Advanced Research in Management and Social Sciences, 3(3), 1-11.

22- Lederman, J.S. (2009) Levels of Inquiry and the 5 E's learning cycle model. Monterey, CA: National Geographic School publishing. Retrieved from, http://www.ngspscience.com

23- Mataka, L., et al (2014) The Effect of using an explicit general problem solving teaching approach on elementary pre-service teachers' ability to solve heat transfer problems. International Journal of Education in Mathematics, Science and Technology, 2(3), July, 164-174. 


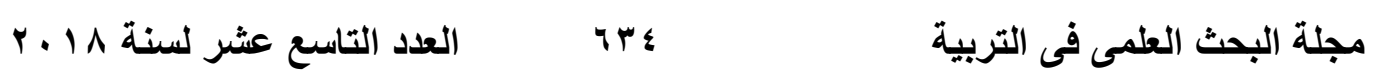

Https://doi.org/10.17226/4962

24- Opara, J. \& Oguzor, N. (2011) Inquiry instructional method and the school science curriculum. Current Research Journal of Social Sciences, 3(3), 188-198.

25-Tandogan, R. \& Orhan, A. (2007) The effects of problem based active learning in science education on students' academic achievement, attitude and concept learning. Eurasia Journal of Mathematics Science and Technology Education, 3(1), 71-81.

26- Wenning C.J., (2005) Levels of inquiry: Hierarchies of pedagogical practices and inquiry processes. Journal of physics Teacher Education Online (JPTEO), 2(3), 3-12.

27- Wenning, C. J. (2011) The levels of inquiry model of science teaching. Journal of Physics Teacher Education Online, 6(2), 9-16.

28- Yu, K., Fan, S. \& Lin, K.Y. (2015) Enhancing students' problem - solving skills through context - based learning. International Journal of Science and Mathematics Education, 13(6), December, 1377 1401. 